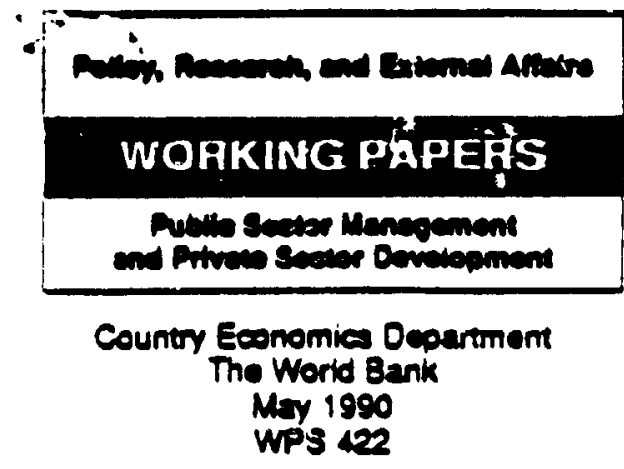

WPS- 442

\title{
Civil Service Reform and the World Bank
}

\author{
Barbara Nunberg \\ and \\ John Nellis
}

\begin{abstract}
Some argue that the complexity and uncerainty of civil service reform place the field outside 'ne Bank's cormparative advantage. But a retreat from civil service management reform is cantamount to denying the crucial importance of govemment administrative capacity to implement economic and social programs. A more realistic approach is to try to learn, through trial and error, how to make such programs work berter.
\end{abstract}

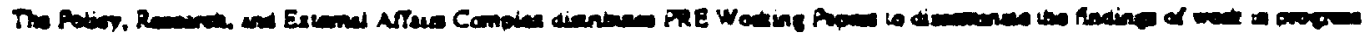

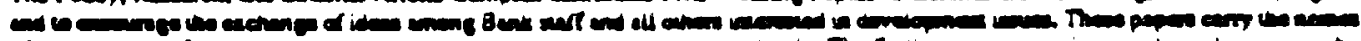

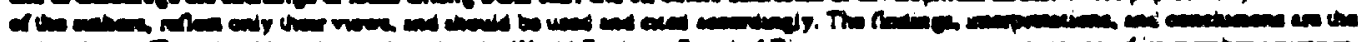

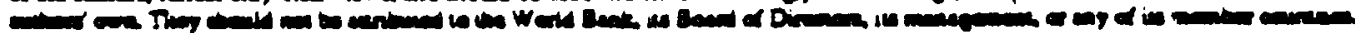




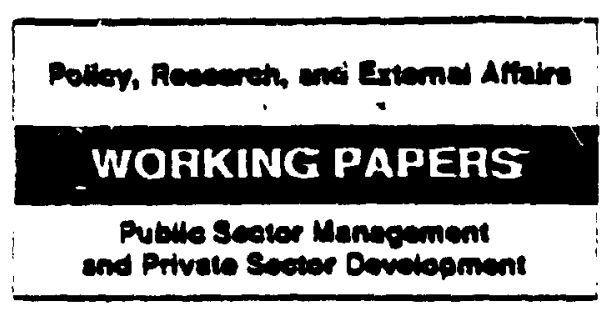

This paper - a product of the Public Sector Management and Private Sector Development Division. Country Economics Department - - is part of a larger efforr in PRE to assess the Bank's accomplistuments. problems, and prospeces in the field of public sector management. An eartier version of the paper was presented at a December 1989 conference on "Irstitutional Development and the World Bank." Copies are available free from the Worto Bank. $1818 \mathrm{H}$ Street NW, Washington DC 20433. Please contact Rose Malcolm. ruom N9-055. extension 37495 (50 pages with tables).

After reviewing civil service reform work in the Bank. Nunberg and Nellis reach cerain conclusions:

The impact of Bank programs to contain the cost and size of civil services through emergency reform of pay and employment policies has so far been negligible. Reform effors have not been ambitious enough; meaningful change will require more forceful reform. Middle-range measures such as voluntary departure schemes and earty retirement programs are useful but are not a substituce for biting the bullet.

Whether more aggressive reform is feasible is pardy a technical but mainly a political issue. But in the fow countries where reform has been carried out, the political costs were lower than most govermments (perthaps even the donors) expected. This may have been parily because of the surprising capacity of labor markets to absorb surplus government workers and pardy because of the skillful handling of reform.

Functional reviews and competency lesting provide symbolic assurance that the reform process will be fair. Retaining. redeployment. credic and public works programs for redundant employess are symbolically and politically effective but have limited practical impact and are administratively difficult.

The Bank should no longer encourage or support mecthanisms such as topping up executive-level salaries for key government posts unless such incentive schemes are part of an acticn strategy for long-term structural reform.

Technical assistance loans (TALs) for civil service management should probably provides twice the present amount of staff supervision and specialized experise.

Such technical assistance jans require more time to prepare and implement than do infra. strucure projects. They often get shor shrift because of their dependence on the scheduling and requirements of strucrural adjustment lending On the other hand. without SALs, many civil service reforms in TALs have no reeth.

Most Bank activities have concentrated on shon-term cost-containnent measures. More emphasis must be given to longer-term management issues if sustained improvement in govemment adminisurative capacity is to take place. More attention must be placed on devising a coherent, overarching strategy and decailed lactics for civil service reform.

Some argue that the complex and uncerain narure of civil service reform places the field outside the Bank's comparative advantage. They argue that the Bark should confine itself to helping define economically rational policies. such as the appropriate. affordable size of the wage bill.

Bus the Bank cannot identify the need to remove $X$ thousand surplus personne! and assume that the job of removing them will be carried out by the government or a bilateral donor. The challenge for the Bank is to design projests thas have measurable shor- run costcontainment goals but realize them in the context of a strategy to solve the fundamental management problems in the long run.

The PRE Worting Paper Series disseminates the findings of work under way in the Bank's Policy. Resezreh and Extemal Affars Complex. An objecure of the senea is 0 get these indings out quickly, even if presentations are less than fully

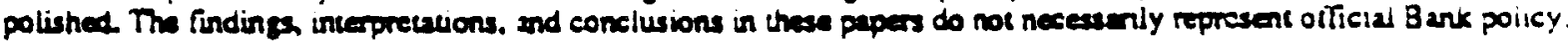


Civil Service Reform and the World Bank

\author{
by \\ Barbara Nunberg \\ and \\ John Nellis*
}

Table of Contents

Introduction 1

Part A: Pay and Employment Reform: Short-Torm Issues 2

1. The Problem: Analytic Approaches 2

2. Recent Bank Operational Experience in Civil Service 5 Reform

3. Cost-Containment: Operational Approsehes to Pay 6 and Fmployment Reform - A Procress Report

4. Impact of Cost Containment Reforms 21

Part B: The Long View: Civil Service Management 23

1. . Components of Rationalist Reform Efforts 25

2. Implementation Issues and Lessons in Development 29 Management

3. Observations 33

Part C: Conclusions

Tables $\quad 37$

Annex 49

- With the contribution of Louis de Merode (AFTPS) and research assistance by Meera Balasubramanian. 


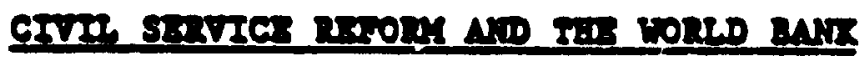

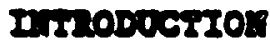

The cuphasis pleced by the World Bank in receat years on the mafor orerhaul of developing country econoniles bas accentusted the importance of adequate public

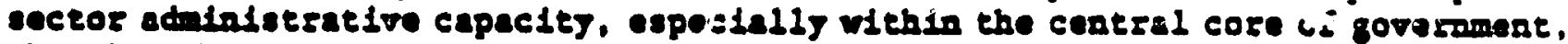

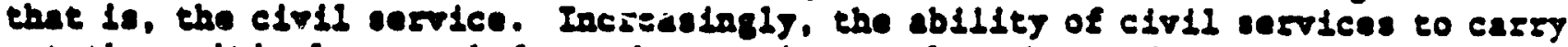
out the eritical -a much lese the routlae - functions of govermment bas been found severely defleleat. Furthermore, the size and cost of many civ1l cervices have been dectand excesefre and have thus becon key targets of adfusenont. In a real sease, this growling concern with contalning the size and improving the performance of the cloll service sigatfles nothlag less than the "redimasioning" of the state, reflectlag a fundamental shift in the direction of the sank's own pobleter. The now widea is to "manage less -. but better."

This paper surveje recent Bank experience in civil service reform, and begles to sesese the progress made. To the extent that corclusions bout "rlche" and "wrong" otrntegles can be renaonbly drawn, som guldance is offered. whth the caveat that it 18 too early to offer definitive policy proseriptions is this eres. Kost operatlonel and eren pollcy work on these

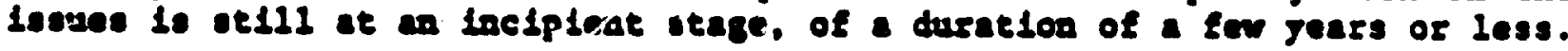

The paper focuses on two soparate but related aspects of civil service reforn work in the Bank. Oae deats with the sbriter-tern, cunsgercy steps to rofor public pay and coploynat pollcles. These reforms usually focus on ansures to contalo the cost and alee of the civil service, mostis in the context of etructural adjustingt leadlos. The other set of reforma are those dealing vith loager-5ange ctoll cervice strengthening efforts, scon of which may support various of the neser-tern sost costalomont masures, but wost of which are directed tomed ongolog, sustained masagempet improvemeats. Many of chese

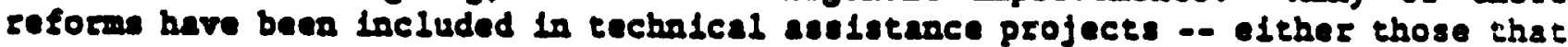
stand alone is "development mangemane" operatlong or those that constitute direct instdeutional support for specific sctions taken to SAls.

Many of the lasues discussed is the paper bere been the subject of earlfer World Benk reviows. I Meerial from these analyses is egathesized and updated where date parmit. In particular, some of the paper's concepts and much of its findings stem from resench currently belog conducted by the Africa Techrical

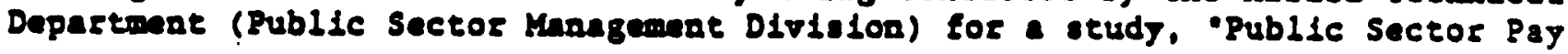

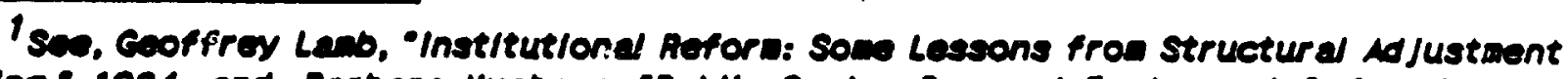
Lending," 1984; and, Berbera Nunberg. "Publle Sector Pey and Employment Aoform," World Bank DIscusalon Papar No. 68. 1989; and Aovlow of Publle Soctor Manageanent issues in Structural ddjustiment Lending." World Bank PAE Working Papar. forthoowing 1990. 
and Buploymat Reform in Africa," fortbcoming in 1990.

The organization of the paper is as follows: Part A focuses on the shortterw pay and employment reform lssues. Section I reviews some curzent analytic approaches to the goverrment pay and employmant problem. Section II discusses the Bank' experience with these reforms through lts lending operations and tries to assess wheif ovetall impact so date. Part B of the gaper examines the longerterm cifll service managemant issues, analjzing the maj $\mathrm{t}$ tpes of devejopment management lattlatives undertaken through recent Bank operations. Conclusions 850 then drawa bout this experiance. The flanl section of the paper ateampts to drew the fladiags of part $A$ and $B$ together and offers recommendations for future rork.

Part A: Par and Implorment Reform: Short-Term Issues

\section{The Problem: Ansirtic. Approsches}

Recent analytle work on publlc pay and employmant lssues bas provided a general understanding of the broad outline of the problem. Governments in many developiag countrles are unable to mange and finance thetr civil services. Drdanes suggeste '.. declining morale and work effort on the part of government workers, problem lo steffing large numbers of skilled positions, a paucity of complenentary inpute in producing govermmet services, and locreasing lmbalance betwen the demand for goverrment services, and the proviston of public goods."

Ciril services in many developlog countries are ton large, too expensive and lasuffictently productive; and cloli servants, especially those in managerial postelons, ere poorly motfvat.ed. They are too large in the broad sense that in many states the public sector ts over-exteaded: 1.e., It possesses too many agencies and organlzations, chargod with too broad a san of responsibilities; and in the narrower sense that too many of these agencies employ numbers of people excessive to requifements (in the sense of people and skills needed to fulfill officially assigned economic and administrative tasks). They are too expersive in the sense that publle sector wage bllls constitute too high a percentage of total government revenues, and account for too high percentage of GDP. The egents withis cirll services tend to be poorly motivaced in that rcmuneration scales for upper end middle managers are low, often extremely low, in couparison to those of coughly equivalant posts in the private and frequently the parastatal sector; and wages are often severels compressed --the bighest pajd

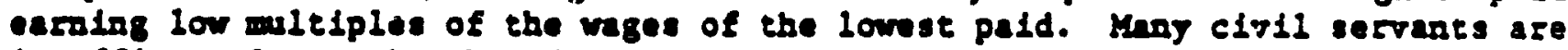
lanufficlent productive in the sense that they do not fulfill the tasks assigned to them (they are lneffective), or they carry out their assignments pertially, with great delajs, at blgh cost (they are inefficieat).

20avld Undauer et 브., "Covernment Wage Pollcy In Afrlca: Some Findings and Pollcy Issues:" Morld Bank Research Observer, Vol. 3, No. 1 (January, 1988), D. 1. Part/cularly acute for Africa, such probleas are also increasingly present in countries as goographlcally dlspersed as SrI Lanka, Bollvla, Horocoo, and Argentina; to name but a fow. 
Analgsis withio the Benk on these issues has tended to focus on four
problems:

Exceseive public sector wage b11ls. Excessiveness is a subjective quailey, one for wich no clear measurement methodology exists, and no standardized approach ts applled throughout the Bank. The oxtreme cases are easy to identify: 1.4.. where public sector wage bills become 30 large that they begin to "crowd out other high prjority lioms. In general, the wage bill is measured against one of the folloving: the overall government budget; orerall gove mment revenues; GDP; or total recurrant expenditures. The latter measure is perhaps the most cownon, and the degree to which non-personnel recurreat expenditures (such as those for supplies and malntenance) diminish in relation to personnel oxpenditures is taken as a key slgnal that the wage bill is inappropriately bigh.

Surplua numbers of cloli servants. Although obvious 1 g gelated to the size. of the vage bill, statements about the "appropriate" nubier of cioll servants are often derived ad hoc from the proportion of public sorvants to the overall population, to the modern sector labor force, cr firom somowhat casual observations of "too man people siteing around doing nothing." Sometimes the sate of expansion of publie employment is taken as a varaing sigmal of surplus numbers in govermment. Clearly, the definition of what constitutes "too many" in the public sector mast cossider the relative role of the state in the economy, the level of e country's divelopment, and the relative importance of the state as a pimary source of or iticel petronage and social velfare. To 1dentffy a persosnel surplus, most .orld Bank reform operations rely upon the lndicator of insufficient operatiog budgets for supplies and malntenance.

Erosion of Public Service salseles. In may countries the level of real public sector salaries -- and particularly cloll service salaries -ob s eroded substantially over time, The result 1 s remuneration that is too low either to sustain lower echelon workers above the poverty level or to attract and retain needed skilled personnel. Real remunerations are slgnificancly affected by the rate of lnflation and the regulartey and nature of salary adjustments. Dechines in real weges have often been cushioned by elaborate allowances or non-wage benefit structures that in some countrles have become an increasingly important part of the overall coupensation package. A pervasive irony affilets many ccuseries; 1.e., the overall salary blll 1s too high whlle wages are too low. This dilewm is the product of jears of trade-offs, given flscal constraints, in favor of biring growing numbers of employees at diminishing salaries. Wage erosion is particularly a problem where there exists an alternative market for public servants, elther through a beter paring parastatal sector, a domestic private sector with higher salaries and benefits or an intermational market to whici blghly akilled public servants may migrate.

Hege Compression. In many casos, compression of the ratio of top to bottom salarles bas increasingly been ldentified as a serlous constraint on governments. ablitey to attract and retain qualifled personel at the middle and higher

3rhls section ar aws heavlly on Nunberg. 1989. 
10vels. Hage compression is pertially a function of expansive emplojment polletes as dlecusesd above. but in some countries it maj also derdve from regime prefereaces for egulitarian salary structures. This, is turn, may hinge on the ideologicel cherecter of the regime or the degree te which its political support 1s drawn from the lotrer socloeconomic strata.

Mngy of the general principles suggested above are derfied from the only avallable date bese; 1.e.. receat emplrteal analysis of rege and amployment practices in a group of African countries." The general analy in and sector work carried out in the sank (and olsentere) as well as obsezvat1or gathered through operetional experience conflem these flodings for a broader range of cases. These flndinge represent a signifleant advance in our understanding of this phoucunan. Indeed, the low vage/high emplojwant scenario in depressed meronconcontes turns on lts head provlously sccopted wisdon of the government as bigh rage-giver. Couparistive data that would permit precise measuremat ur

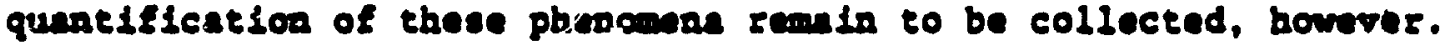

In short, the issue is difficilit to analyze. The reasoas for this are several. Cortainly, a standardized view of the proper functional span and size of the state romeles elusive, despite the rweplng re-conggeace of liberal notlons of alnimalist government. For example, crea in societies in broad 1deological agrecinat as to the approprlate role of the otate, there $1 \mathrm{~s}$ no unerguable crtterion that determines the apyroprlate number of ministeles, or

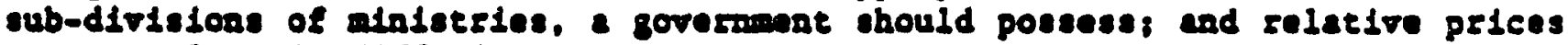
(wage scales) in differing labor anzkots atght provide sound economic ressons for a wide rariation in cuplogenet levels in organisations having roughly equivalent obfectives. Furtherwore, the sange of colutions to this que thon may vary by cotatry, region, of level of industrdalization. On the other hand, there 18 no cless. Ilnecr peth to development in this ragards large seates with high numbers of ctull servantes per cepltz are prevalent in both the developed and underdereloped world.

Vexing mecsurement questlone are unresolved. The methodolog for determining appropriate vage levels for private and public sectors continues to be debated. Wajs to measure productivity for central goverament agencles have been the subject of a vast but incoselusive literature. Questons remin about the potential consequences of public sector retranchmant programs. The relative cepacley of differeat types of labor markots (rural-urban, formal-informal) to absorb redundant labor fron the public sector ls poorly understood. And analytic techniques for determinlag the diract and ladirect, upstrenm and drwstream costs and benefits of varlous reduction in force scanarios ere st111 very primitive.

Polfelcal economy feutures of public pay and anployment practices bare only begua to be analyzed. The real as opposed to the percelved political risks of goverrmant retrenchment programe are nettber known aor at present calculable. Which are the kes bureaucratlc and socletal coalitions that figure in employment and par reform? How mach raform is politicaliy feasible for a glven reglme to undertake under what conditlons?

\footnotetext{
Lindauer ex al.. og. clt.
} 
There 18, in sum, a lack of agrenment on guiding analytic principles, a lack of flrm mosurament criterie, and a great reglonal variation in the tnenalty of tis syadzom. Nonetheless, a growing body of empifical evidence or this topic -. cccumulated minly through Bank lending experiencs -. provides ouffictert informetor for at lease a preliminary examination. The section that follow bighlights the more striking features of this experlence and then draws general lessons abot: the implementation of these trpes of reforms.

\section{Recent Bank Operat Ioned Experience in Civil Serrice Reform}

S1ace 1981, civil cervice geform has featured promineatif in 61 Bank leading operations. Of these, 38 were structural Adfustmant Loans or Credits (suls or SACs), and 23 rere Technical Aselstance Loans or Credits. (Table 1 lists Bant operations with clvil service reform components). S Four operations bave been

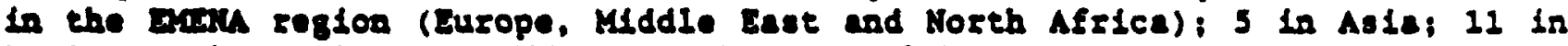

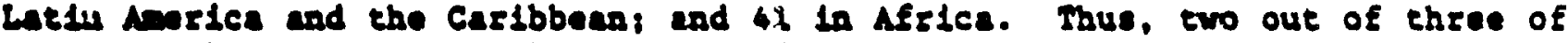
racent Bank-eupported civil service reform programs have been in Afrlca. The angentude and lotenstey of the 1ssus ts clesely grostest in that region; and efforts discussed below are minly, though not exclusively, taking place in Afrlca. (Table 2 show the reglunal distribution of Baak oparatlons with civil service reform componats by lending instrumat.)

Activity 18 quite now in this fleld; prior to 1981, the Bank was only tangentialis levolved with c17il service of administrative reform -0 except for

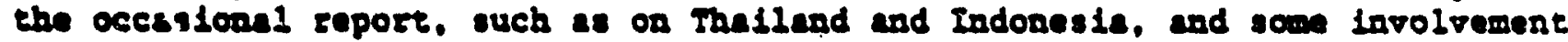
by educstional opecialists on civil service tralning inseltutes -o and wat was done we minly on the project, not the pol1cy. level. It has been the Bank's cates tato policj-besed lending, with lts emphasts on demand management and Irprovlng the performance of adjusting governments, that hes led to the lncreased involvemant with civil service issues.

The wost lmportant set of ressons for the inclusion of civil service reform In recent adjustrat operations center eround the issue of budgetary burden, the recogatition of the heary, flscal bi len posed by large wage bilis. For extrame example, in the eariy 1980s, following rapld increases in the aumbers employed, many african countriss saw tbelr wage bilis riso to account for more than balf of total government revenues. Such increases ware tolerable (though aever vise) a long a total revenues lacreased. But with the prolonged economic cr1sis and 1ts attendant stagnation of growth to govermment revenues, the difficule-to-roduce rage Ulll begins, es discussed in the preceding section. to "croud out" other critical current expendituress malnterance and depreciation, the proviston of essential supplies and equipment. This led to the increasingly cownon itustion of teschers without books, doctors lacklag medicine, postal workers having no stame to vell. etc. The recognition that this was taking plece led som goverpments to inftiate their ow rationalization measures. It led the Bank lacreasingly to include blvil service reform in adjustment

Sseveral other types of Dolloy-based lending operatlons, such as Reconstruction Import Credits and Econom/C Recovery Credits (AICS and EACS), were counted among the suls. Thoy are ltealzed in Takle 1. 
operations. Thus, the prtanty resson for the Banic's more recent, intense and direct epprosch to cluil service rjform bse been tho need to help borrower goverminate manage domand, to contisin and reduce a mor cost area.

The second set of ressons centers around the perception of low effectiveness and efficiancy levels in govermment adminiscrations, attested to If crittcal cases by the degradation of the state-provided (and supposedly state-

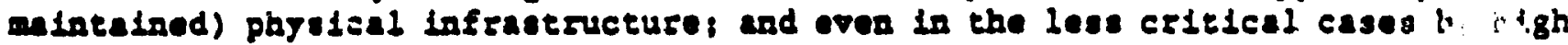
traneuction coets, pervesive delaja, and the prevalence of corruption. Improvemant of effectireness and efficlency lovels 18 seen as the esseatial ano Uleimnte goal of administrative referm. From the outset it wes thought, and experieoce tias conflrosd, that ralsing these levelo is a couplicated, problematic and longer term effort. The relation of cost contalrment measires to efflctency/affectivanes promotion ls thus anslogous to the relation of stabilizetion to the restoration of growth to adfusting econoules: 1.e.. 1ssues of dennad anagemant take precedence and are ensier to effect than restarting of growth. For civil service reform one could easily argue that is should be the other wey round, that assessing what the organizations of the st ite need to do. whet resources, physical and human, they aeed to do 1t, and bow to go about dolag it, should precede the question of cost containmant and reductions. Noateheless, because of the magnitude and latensity of fivcal problems, the cost costadoment stops have been seen as the flrst priosity.

3. Cust-Conzalnmont: Operat Lonel Approaches to Par and Emplorment Reform - A Progress Report

Thts sect 100 exsuines the most recent Bank expertence in pay and employment reform, andjzing the short-term, cmergeacy mesures taken (mostly through adjustment operations and companion technical assistance projects) to contais the ize and cost of civil services. The focus is on the period since 1987 when Bank-supported pay and employwent reform was last reviewed. The purpose here is to provide a progress report on approaches to the problem, concentrating on theis implementation. New initiatives that have been devised in the intervening perlod are also analyzed. The following section evaluates, on the basis of avallable dats, the overall impact of these measures by examining general trends in wage bill containmant, employment iocreases, and rationalization of semuneretion structures.

Batk operations deallag with govermment pay and employment lasues have supported a range of reform approsches. Many of these have been implemented on - trial and error basis, and we are only beginning to leata about which are working and which are not. (The key messures takes by countries to reform pay and employmant polictes are ummetzed in Table 3). With regard to cost. contaloment, various of these actlons have been ranked on a continuum of political difficulty ranging from the easiese -. undertaken first - to the most difficult. The maln steps taken have been the fillowing:

-- the elimination of "ghost" or gon-existent names and workers;

-- the elimination of officially sanctioned poste which are not curreatly Ellled;

-- the retreschment of temporary or 'easonal workers; 
-D the eaforcemant of ret bement age (or retirament efter $x$ years of service) selpulations:

-- the freesing of recrulement:

-- the elimination of juaranteed entry to the civil service from the educational or tralning system;

-D the "volusesry" or lnduced by lnceatives, retirament of surplus workers; and finally

- the dismisest of serviog civil servants. Includings

A number of techolques were utilized to support the steps outjined above,

\author{
-- Cirli Service Coneuses \\ -. Punceloral Rovims \\ - Pajroil Computerdzation \\ -. Zompetency Testing \\ - Public Information Campaigne \\ -. Radeplojwant Tralaing and Crodit Programs \\ -. Salary Supplemates \\ -D Sk1118 MobllizatLoa--Senlor Executive Programs
}

The limplementation of these masures are diszussed below.

Cloll Service Consuses, Parzoll Computerizet ion and Cleen-Up; and Ghost Reduction reseures

The reduction of civil service cadres through the elimination of ghosts 6 -- the flrst and lesist politically sensitive approach to emplogmant reform -appears to have been an effective technique in emergency cost-containment programs, although comprehengive data on reductions accomplished through this mathod are not jat avallable. (Table presents varlous measures taken by selected countries to reduce employment.) For thana and Uganda, at least, ghost - Imination represented a useful instrument of employment reform. ${ }^{7}$ Ghost removal we also clidred to have been a significant feature of zeforms in vazious othas countzles. After atafe audlt in 1987 in Gulnea, for example, approximately 1091 ghout anmes we stricken from the clvil service payroll. In Cameroon, - approximntely 3000 flct it bous names were elininated. In general, ghost reduction

Gonosts are nawes on the payroll, recalving a wage, who cannot de shown to ex/st physlcally. Thoy are workers who have diod, retired or otherw/se left the elvil service but were never recorded as such. They are flot/tlous persons whose pay is clalmed by others. They are varlants on a naw with on borson recelving two or more salarles.

Toata on ghost rowovals in chana are very tentative and remaln to be verlfled. covernment clalis that 11,000 ghosts were ellminated through neadcount and census exerelses have not yet been valldated. In Uganda, approx/mately 30,000 gnosts have been ldentifled, but there is no evldence that these naeses have been reasoved from the Dayroll as yet. 
Lecuse low poldelcal costs because the only opposing constltuency are the system abusers themselves. Lor wom a public admisston of fraud would be necessary to stake a clate to cuntinulng pagment. Indeed, In none of the above cases did ghost removal generate a public outcr.

The fisst sep in ghost removal is, normally. a sivil service census to determine the aumber and type of goveramant amployees. In mas countries, such a poll will be the flrst time in magy jears (or perhape the flrst time over) an attcopt bae been made to got an ecsurate pleture of public amplojwant. The aesd to eveabliab who 19, and wo lo not, legitimntely earolled on the civil service rosters and pajroll is paramolite.

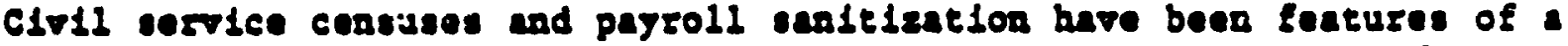
aumber of pay and auplogwant reforms as show da rable 3 . Fow reforming

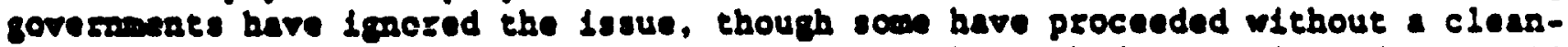
up exerc1se. Laos, for example, 1s raported to have shod an estimated 10 to 30 perceat of governmat workers ising a payroll l1sting as the sole form of personel records. Int nost countries, though, a prjor date collection and

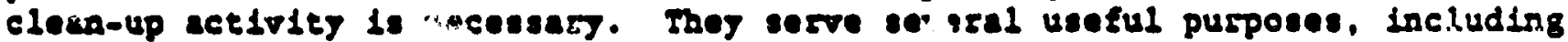
quantifying the often laxge ranks of tapporary ataff; providing laformation lesding to the enforcumont of the statitory retirament age, and, most important, rogularizing payroll lists through the elindantion of ghosts.

The usefulaese of - ceasus is releted so lise lovel of couproheastreases

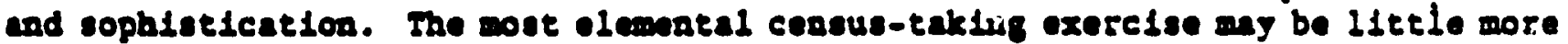
this : "hoed count" which ofmply eatebllobes the aumber and the otracture of government wolojwate (1.e. the number of cuplojees at various professional levels or in different reglonul locatlons). Censuses of the head coune vartety are usualis designed and carrled out by governmats themeelves. (At early points In the reform process, Ghane, Gambie, Gulpes. Boldvis and Oganda and others performed bead counte on thels ow without technical asslotance.) The resules of these counts here often bean disappointing. Findings have been incomplete and lasccurate, minly because they beve been based on existing civil service rolls rather thas veriflcation of physically present employees. While not expensive to undertake, bead counts of this sort can st111 be a waste of scarce zesources, ince they mist usually be followed by more rfgorous censuses carsied out by outside consultants. On the other hand, even flawed head counts can serve useful purposes. In Ghase, the intelel civil service surver revealed the overall structure of cuplofwert which clesely indicated orerstaffing at lower grades of the bureaucracy, providing a seating polat for policy reform discussions.

Eren consuses that are wore sophloticated in their velidation nethodologles mag have only limited applicatlose. Succavelve censures carried out by intermetional consulte i In Ghana (there were throe all told) used the payroll mechanden to count civil esvants, but they did aot acturlly verify the phyeical existeace of emplojees -. the rationale being that just gettiog fraudulent names off the payroll was good enough. Heither did ther establish durable links between the computerized payroll syotem in the Kinistry of Flnance, the personnel records in the Office of tho Hend of the Civil Service, and the annual budget. The censuses did, however, provlde important, one-shot, baseline data to begin the employment raduction program, thus fulfilling an essential 
function.

he lease two problans can be suen with the Ghanalas approech. Oee is that, whour the lostitutional capacity to utilize the date is a computerized monitortag syscem, the quality of census date is subject to rapid erosion. Rasults become outdated quickly as new recrults opter the sivil sorice (openiy or clundestioely) and as others leave. Personal data which mighe provide an crerall proflle of the admintetrat10n 130 change, so that loformation about especte such as the age struceure and promotion patteres is no longer valid. Moreores, It is lmportant to be able to capitalize on the results of the census quickly because the parience of civil servants to endure succeseive surveys ware thin, as bes been the case in Ghana after three such exercisus in a period

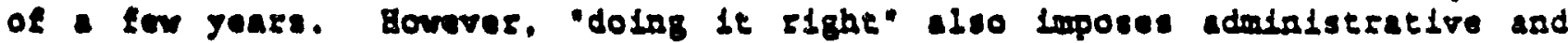
Inancial buzdons. In Kadagascar, the coasus was more rigorous: enumerators were blred and cloll servants had to be present at the plece of census. The penalty for aon-cooperation wes severe: suspension of paycheck. Thus, participation was hlph. The cost of this elaborate exercise was a nor-trivial flve percent of the vage b11l. however. Eurthermore, the organtzat fonal requitements for axecution of the cansus -- 1.e. organizing review combltece, anumerstors, census canters at both central and district levels .. were also considerable.

In goneral, recent experlence with jensus design and implemencation sugserts that usch mechadsme are important flrst stepe to getting the roform prosese woring; that their design should be kopt simple, but atrategic in the cerase that they should be concelted as par": of the establlebment of an ongoing ijote of controle, and thel their successful conceptualization and Luplemantation geverally requifes axtermal techolcal assistance.

\section{Eirezing Cloti Service Recruitment}

Freezing or liniting civil service recrultment is an oitten spplied mechasism for reducing government employment. It is onls anrginally more politicalig difficult than ghost oldmination. (The difflculty is dise to the potential disruptions that might be causud by aspiring civil service csadidates.) Hiring freezes have been witely used, with vargtag results, in a number of couneries, lncluding Conta Rica, Ghana, the Central African Republic, Congo. Gambla, Gabon and Muritania, among others. A variety of wechanisms were used to administer these policies. Senegal, for example, instituted 6 hifing freeze 10 1983, and created a hgh-level lnter-minlsterlal commission so supervise the process. The comission, the secretariat of which met weekly, review d all departures from the civil service, with a view to decermining (a) if it were necessary to flll the particular vacancy, (b) if so, with whom, and (c) if not whether the etaff of the orgunization could be lediesd by ore or whether the organization had some preseing personnel aeed in another aree that justified 1 position. Between 1000 and $\$ 500$ reductions vere reported to have been affected 10 the first two jeaza of the comblsolon's operation. This experience, and a - inilar but tionger scheme in the Ceritral African Republic. are sumarized in the "Box" on cost containment in Annex 2. Variations on this thene include allowing hirlog only if it does not result in aet creation of civil service posts (Renjo has tried this); or limiting hirlizg to essential professional staff (in force in Malawi, Mall and Nigeria). 
Autometc hising has been discontinued in some African countries which had traditloonliy guaranteed govermment jobs to school graduates. (Examples ere CAR, Congo, Gut ia, Mall, Somlia, Sudan, and Senegal.) This reform measure turns out to be somenthat complicated to implement, as the case of Sngegal demonstzates. When the hiring frueze was instituted in senegal, there were more than forty government schools and training centers. Prlor to the fresze, entry to these centers equalled antry to the civil service. The freeze forced the Senegalese to cur:all sererely the ontry to and ectiolties of these centers; the result to date has been the continued existence of most of these lostitutions, but with ever-decliaing aumbers of students or tralnens. Still, the Senegalese govermmat, as moot ockers faced with thls problem, malntained its employment condtmant to those already io the trainiog pipeline, maniag that it may be somo jesre before an effect from this particular element of restructuring cas be parceirad. 8

Is generel, the record of higing freezes appears to have been mired. Where they bave algaifled a hale to atomntic civil service recruitment from universities or public sdmialstration training lastitutions, they apply a - lgalficant brake on civil service expansion. But recrultmant freezes may constrada govermment froi achleving the necessery skill mix through renovation of lts cadres with roung entrants. Moreover, for some clvil services, biring freeses any be no bre effletent in eldminating redundant c1vil servants than

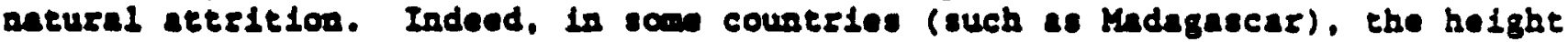
of cifll eervice expansion took place in the early 1960s, when masy now recruits mro hized, causing a persistent bubble do the clvil service rolls. Hiring then leveled off. It could be argued that in these instances it makes sense to let antural ettritton through normed rethrowant, which will occur over the next fow jears, take care of this surplus.

\section{Suspension of Autometic Increases and Advancements}

One cost containment measure which has come loto lacreasing use in the most recent operations ts the suspens lon of automatic lacreases and step advancements. Tuis is of particular relevance in the francophone African countries where adrances in grade and pay tended to be based solely on jears of service. Thus, freesing recrultment or even modest reduceions in the total aumber of the civil servants sometmes hes had but a limbted effect. Senegal, for example, froze recruitinent as early as 1983, and even succeeded over two years in reducing total numbers. St111. It found that automet ic step and grade lncreases kept the wage b111 od the lacrease; the fiscal result of whe the sebegalese regarded as an heroic and politically dangerous effort was reduction in the annual average

- Tho Senegal case ralses another lasue: the parallel raforn in the parapublle sector is resulting in reduced tiansfors to and, it is nopod. oventuaf reduction in the nunbers of publle enterprlses. But many of the staff now eaployed in senegalese PEs are "tenured" CIVIl servants who chose or were asslgned to service in a PE. If they are dlsalssed from the PE they have the legal rlght to a post in the clvll servlce proper. Legal rights can be anended, of course, out only at the expenss of time, of fort and the expendlture of some of the government's pellt/cal base. 
growth rate of the wage blll from fourteen to nine percent. The suspension of auconatic advances is an element of recent reforms in five countries with Bank program, Lacluding Dominica and Mauritania. In addition, Burundi and Cote d'Ivolre tamporarily ousponded automntlc pay increases to dampen drift factors. Both Burkina Easo and Cote d'Ivolre also restructured thelr pay systems so that promotions are now offered on more selective basis rather than granted automaticadis.

Strict enforcement of retirement for over-age civil servants has been a festure of a number of reform programs (including Cameroon, Gabon, Costa Rica, and Benin, Senegal, Ghane, and Gulaes). In Guinea, for example, the Bank supported the enforcement of atipement program in which all civil servants over 55, or all those who had completed thirty jears of survice, were to be placed in autcontete and effective retirement. The result wes a reduction of over 7000 cadres. While presenting an optLon for emplojment reduction that causes few political ripples, the impact of such programs hes been minimal. This is pertis due to the unreliability of most informntion about age -. even when gathered by moderm surver eechniques through civil service censuses -- and to the orerall sge profile of most civil services io most LDCs. This is especially the case is Africa, where the average age of cioll eervants is below 40 . Thus, the removal of over-aged employes usually targets a small group.

\section{Early Retirconet Programs}

Increasiagly, countries find that implempnting the more "essy" options does not result in sufficlent cost cutting. They thus begin to explore ways to sctully cut beck on the numbers of serving complojees. Even at this stage, governments are lostbe to take the most difflcult polftical zoute; that of involuntary dismisal. A number of strategies have been tried with varying degrees of success. Oeunlly, these options are offered as one among several in - intred approsch to staff reductlons.

Early get 1rement is an opt lon that has been proposed in several countries, including Senegal. This program targets civil servants within a few years of normel retirement age, elther paying them a Iump sum separation package with pension benefits to begin with normel retirement age, or by starting their ponsions at the early departure date. Although systematic analysis has not yet been performed on these egpes of programs, theis benefits (in terms of numbers roduced and rage bill decreases,) would seem to be minimal and their costs ignificant. First, the net preseat value of the savings stream 1s likely to be low since the euvings only represent three to four years of staff reductions Insteed of those that would occur if younger workers were to be removed. Furthermore, early retirement programs target the most experienced employees - both at managerial and support levels. This poses a particularly acute cost for those civil services in which once high standards of professional performance and tralnigg have broken down. Early retirement means that the collective experlence of the older employes, who might be the sole keepers of the efficlent flame of an earlier ers, is lost to the newer generation.

\section{Voluntary Departure Programa}

Voluntary departure schemes have been a feature of several civil service 
reform programs, Including those in Gulnes, the Gar, Mall, Kenye and Somalla; ooe has been proposed for senegel. In general, voluntary departure schomes are viemed as politically palatable because they are not coerciva. Voluntary departure programe are problemat1c, however, In thet they often attract the best and beightest civil servants; that 1s, those whom government would most wish to retain. Carried out on a large scale, voluntary departure schemes ere expensive. In Guines, voluntary departure with an essociated premium wes to be finenced with an earmarked fund of GF 6.5 bill10n. The boneflts involved a three-option plan Eron which departees might choose tos (a) draw a selery with accompanjlag 5 ice retlons for 60 monthe: (b) take 40 percent in cash and the ramninder in regular salary pajmats; or (c) take a share of the severance allownce as a down pajment on a new private sector business renture. In its proposed roluntary departure schem. Seregal would offer 60 monthe of selarles to voluntarily departing clvil servants. The government has requested elnancial support for this scheme from the Bark.

Mang countries would prefer to carry out staff reductions exclusively through voluntary departure programs, particularly if thes can find extermal flancing for a portion of the costs. Honetheless, it seens clear that the monetary incentives would have to be significant (and probably unaffordable) to encourage sufficlent reductions in numbers. On a smaller scale, some civil servants might have a low reservation cost that would permit them to take advantage of voluntary departure incentives thnt were not exorbitant ly expensive for government. In this way, voluntery deperture, when combined with retrenchment, could be a Fiable strategs to achieve significant amplojmant reduction. Howrer, on lte own it is probebly not terribly effective.

\section{Retrenchient}

Rotrenchmat -D the disect and explicit dismiser of redurdant civi: eervantes -a Is the most difficult and pollticalig contentlous measure used to reduce emplojment. Governments have strongly resisted these remedies, and have sdopted them as last rescrt options. Thls reluctance is related to the aature of the state in many developing countries. An important purpose of governments is construed as the distribution of political petronage and social welfare through the provision of public posts to loyal followers and otherwise deserving clients. Overt emplojwnt reduction thus strikes at this basic deflattion of the role of govermment. Moreover, the fear of most political regimes that retrenchment w11 incite destabllizing social uphenval and political opposition serves to stiffen resistance to overt employmant reduction moasures. The task of opponents to staff cuts 1s made that much easiar by feers that the labor absorptive capacity of the private sector ls wenk.

It is thus not surpeising that lovolved Bank staft note difficulties and dalays in couplying with otaff reduction conditionality lo adfustrent operations in the Cantral African Republic, Guinea Blssau, Gulaen, Ghana, Sao Tome and Prlncipe, Senegal, Costa Rlca and Dominica, to nam but a few recent oases. Supervision reports record acceptance of fower dismissals and langthier timeframes than orlginally negotlated; these reports note as well in several second adfusement operations the repet1t10n, in sonewhet stronger terms, of emplojment reduction conditions seen in the flrst operation (SAL 1-" enforce retigement age regulations;" SAL 2-"stefctly enforce retirement age 
Eegulat Lone").

Desplte the considerable resistance of govermments to undertake what they percelve to be polltically rlsky measures, retrenchment if nonetheless taking place in several countries through Bank operations. Ghana, Guinea, Gambia, and GAR (courtiles for which some documented raduction figures are available) are cases in point a of 1989, approximately 27.791 civil servants have been retrenched in Ghane, In addition to those remored from the rolls by other nebanians. In Gulnes, an estimated 4245 hare been retrenched. In the Gambla, fol.owins a census and staff audit, approximately 3350 goverament employees (lncluding 2600 temporary emplojess) were dismissed. And in the Central African

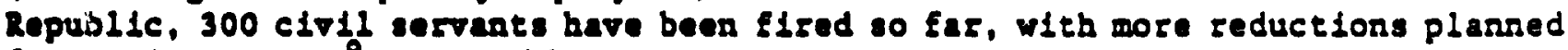
Eor conlas rears.9 (See Table 4 ).

The dats on these rotranchment exerclses are still quite preliminary, and in-dapth analysis of this experlence is only aor belog performed. 10 It is thus poselble to offer only tentative observations on implempntation. One notable festure of these programs was the use of a variety of techniques to deflect political opposition, minimize the social cost of retrenchment, and provide techalcal support to redundancy programe. In Guines and GAR (and planned for Sonegal). Eor eximple, public informeton campalgns were destgaed, with the help of consultants, to laform government emplojees through radio brosdeasts and acwepaper articles, of govermment lotentions with regerd to administrative and flanaclal aspeces of the staff reduction programs. Bank seaff reported positive offects for these efforts.

\section{Testing}

Coupetency exams were used is at least one country. In Guinea, competency tests for oleting civil servants provided technical criteria to determine which personal would be graded as surplus. Those who passed the test were to be retalned, and those who falled would be entltled to a severance package related to the leageb of service. (They would not, however, be able to opt for the more

In fact, wany of tho mochanisas deserlbed in this section have been utllized in conbinat/on with one another, naking It difflcult to lsolate the relative utIIIty or Impact of any single one. In chene, for example, voluntery departure was not st/mulated through eddit/ond Incentlves; the voluntary separation package was the sawe as for redundant workers, thus provlding llttle motlvation for workers to leave of thelr own volltion. At the sane t/me, workers theoretically had the optlon of early retirement, but mould recalve no extra beywents over and above thelr reguler Dension rights. If they chose voluntary ret/rement, however, thoy would recelve the lump sum separat/on payment in eddition to thalr penslon. Thus, thore were virtuaijy no eariy retirees in Ghana, out sow older voluntery departees. Clearly, It was not the nature of the Individual scheme, but its relation to. tho other parts of the staff reduetion program that determined the outcons.

10 systematle analysls of pay and employment roform in three Bank operations (Curnea, Chana and Gambla)ls the subJect of the Afrlca Technlcal Department, Publle Sector Uanagement OlvIslon study in progress, "Publle Sector Pay and Employment Reform In Africa," forthconing, 1990. 
lucrative package offered those in roluntary departure). Recrufement in subeequent years would be determined according to the new qualifications testing. and the promotion of employees retained would follow a logical procedure coupled with training. Although the exams were first geared to university level stundards in Prance for professlonal level positions, the requirements were later relared to fit local capabilities. The objectivity and credibility of the program was validated by the presence of external consultants, and this apparenty anhanced acceptance of the practice. Desplte this acceptance of the priaciple of testiog, the exercise hes proved to be cumbersome to administer, causing conflict and delays in the overall civil service reform program in Gulnes.

\section{Personnel Banks}

Competency testing wes couplad in Guinea with the creation of a special personnel balk where those exployees who passer rxams, but were considered otherwlee redundant, were pleced in a speclal category. These people remain on the parroll for alx months. If they do not find jobs, they are removed and dismissad. Thes also have the option of leaving of theis own volition with a severance package somentat $108 \mathrm{~s}$ generous than that offered to volustary departees. There are approximately 14,487 employees in this category as of this reiting. (Thie figure me loclude som 3400 public eaterprise employees, howeref.) The adminlatration of this personael bank has proved exceedingly complicated, and there is not jet clear indication that ang of those placed in the pool have actually left governmant. There is concern that this category of aployees will continue to lmpose an onerous burden on the wage bill without contributing to civil service productivity. Moreover, the presence in government of an (offlcially) idle class of disgruntled employess ina serve to demoralize other governiant personnel.

\section{Sererance Packages}

Severance payments .. financed by goverments themselves - have accompanied retrenchment programs ln most countries. A comparison of severance provisions is show in rable 5 . While the absolute value of these separation packages is imposeible to compare, the formulae themse.'ves appear to be relatively generous. These formulae are mosty ambelilshmeats upon the besic legal obligations of government to dlsmissed workers worked out through negotiat Lons among various interested parties. The administzation and the size of the severance packages appear to be anong the noet lmportant determinants of the level of acceptance of the overall employmant reduction program by affected emplojees. In Ghana, delags in the calculation and distribution of separation entitjement in the first jesr of the reform program stirred some disruptive opposition among affected clvil servants, for example. Bank staff reported that protests were smoothed over in the second year when severance paymants began to be awarded on time.

\section{Funcelonal Reviews}

In some countries, functional reviews have provided an important rechnical rationale for employment cuts. (Table 3 shows a sample of countries that have carried out functional reviews). These reviews are discussed in greater depth in Part B of this paper. Theif purpose is essentially to audit the functions 
of componeat agencies of govemmont and the number and type of staff presently carrying them out in an attempt to determine the optimal staffing arrangements for basic government tasks. Functlonal reviews ars difficult to administer (they are usualif carried out through technical assistance), and they are tineconsuming. Indeed, as is discussed in detall below, in the two cases where they flgured most promisently in the reform program (Ghana and Gambia) many cif the omployment cuts ectualiy took place before the functional reviews had been started. Nonetheless, It has been roported that the carfying out of these reviewe oven weil lato the implementation of a retrenchmant program provides an essurance that there is at least an intention to purgue staff reductions in a ratlonal, technical. and fuse manner. This assurance has served to dispel. polltical and soclal discontent over the retrenchment programs as a whole.

\section{Redeplowent, Retraining and Crodit Pronrams}

Bank operations have begun to address the issue of redeplorment of redundant labor in thelr reform programs. Several countries have pur together programe which offer tralning for jobs in the laformal sector, credit schemes at favorable interest rates for small business or agriculture, and/or pubiic worke programs. (Chane, Gumbia, Gulaes, and Bolivis offered such programs.) On a techalcal besis. these programs have been less than fully successful; in son Instances their justiflcation may be questioned.

Elrst, retraloing for informal sector activities -- which is where many redundant workers tend to go, may be largely 1rrelevant; indeed, the number of people benefiting from training for carpentry or dressmaking 1 probably quite amal1. In Ghana, for example, where this type of program wes offered through the Programe of Actlons to Mitigate the Social Cost of Adjustment (PAMSCAD), the demand for such training was low. In most countries, the existent training lastitut lose ere not equipped to handle this kind of Informal training. or if the demend were higher, to eccomodate the aumber of trainees that potentially could result from masive lay-offs in the public sector. The administrative costs are high and the potential benefits uncles.. Again in Ghane, an attempt was $1 s 0$ made to provide training through an apprenticeship program. This was difficult to organize, however, and only reached a linited group. Like the other redeployment schemes, this program was undersubscribed. Credit for small business and agricultural activities, another aspect of the program, was also in low demand. In the Gambia, the Institute of Business Advisory Services (IBAS) administered a smilar program which received approximntely 700 applications (out of more then 2000 workers latd off by the government) and provided credit and/or training services to only about 300 individuals.

In Bolivia, a public works program was organized through the Emergency Social Fund to provide transitlonal employment for dismissed in mine workers from COMIBOL, the state mining company. Reports indicate that most miners did not take advantage of these programs, however. Instead, they sometimes used the cash payment provided by a generous separation package to relocate and start enterprises in the informal sector, or to find construction work elsewhere. In Guirea, the Govermment set up a special office, BARAF, (Bureau d'Aide a la Recanversion des Agents de la Fonction Publique) to assist departing civil servants la applying for credit to finance private businesses. Some Bank staff fear this credtt program may have permanently damaged the country's credit 
ojetem, Indeed, there see now on the books lazge numbers of loans to depareed clvll servants that have almost no bope of belng recovered. The Gambis small buspese credit scheme for redundene clvil servants did not fare woll in this respect eleber. Ite loan recovery rate was 30 percont (as compared to 65 percant, for example, for an IEC-flnanced credit scheme with more stringent oligiblilty requiramenta).

This experience suggests thet the technlcal ratjonale for these programs 18 wak. It would appess that masy c1711 servants being retranched asieher aeed nor expect to be retrained or redeployed. Most go lnto the loformal sector for which theze are fow adapted cred1t schemas. It would be administrativejy easier, and would probably havt a more boneficial economic impact, to simply award cash serezance payontes to doparting ataff.

Another point is that redeplojunat programe requize considerable Institut Lonal capacity to administer. In the Gambla, the program only got off the ground one and a half years after retrenchment had bogun. In Ghana, the 1 ag tim wa two and a half jears. In Gulsea, the progran begas on the anticipated date, but proved to be rery difflcult to mange. Irplcally, there are a nuber of institutions wose ectivities mut be coordinated and the preparation requiremate are considerable. Moreover, because existing training and credit lastitutjons are inadequate, aw mechenism often ere required, imposing substantial additlonal costs.

Ftan11y, for sone countr1es, the seed for opecial mechnalsmo to rechannel labor lnto private arkets any be lese thas anticipated. That 1s, there is some prelintens evidence to suggest that labor absorption has bese easier than expected -O or than goveromants eyplcally contend. In Afrlca, for example, urban workers eppear to have moved easily lnto agricultural ectivities. In Bolivia, the abllity of the informal sector to absorb reduadant public sector employees appears to have been considerable. Thus, the technical rationale for retralning and credit is further eroded.

These programs do perhape have an important symbolic value tn the extent that dismlased workers place value on access to thls $k$ ind of assistance, whether they avall themselves of it or not. Such programs thus serve an important political functlon in defusing potential discontsnt among retrenched employees. In geanral, though, It may make more sense to concentrate on severance packages or generous goldon handshakes in destgring emplojment reductions programs, as th1s 1s where mone employee lnterest and demand are fosused.

\section{Remuneration Issues}

Masy of the cost-contadomant mesures taken bave focused on reducing cmployment; but mas steps have also been dizeeted at containing the wage b111 In the agsregate, and te removiag distortlons in the overatl remuneration structure. These masures are discussed below.

\section{Wage Restralne}

Hage freezes are common measures. Full or partlal wage freezes were 
called for lo Uruguay, Seregel, Gambla, Sao rome and Princlpe, Camaroon, Gabon and Tunisis. (Prjor to the Bank' increased lnvolvomont in wage bill reotraist, wage freezes fentured more prominenely as conditions of IN agreements,) Ways of institutiog a wage freeze or at least restralning wages are numerous; h.a. $^{\circ}$ by bolding vages to existing lovels in currant terms; by holding them in constant terma; by allowing increases equal to a portion of, but less than the entirety of the rate of loflation; by setting a currescy unit celling, or by agreelog that the rage bill canot surpass a perticuler ratio (for example, percentspo of government expenditure).

\section{Ret lonelizetion of Remunerat ton}

Increasingly, pay and employment reform programs have also been addressing opecific pay conditions for cifll servants in an ettempt to ramove domotivating distortions in governman ramineration seructures. A number of reform programs have aimed at lmpoving pay condstions, ratlonalizing the overall syatem of remmerat10a, and buildisg an institutional capacity in government to formulate and Implement sound selery polictes on an ongolog basts.

Ret topaltzat ion of the remunarat $10 \mathrm{~s}$ atructure bes been an important reform objeceive. This hes aninly consisted of attempts to reduce the proportion of

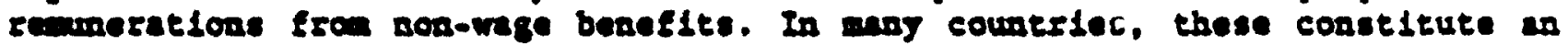
unacceptably large percentage of totel coupensetion, as real rages have beed steadily ezoded by laflation and axpanding aploymant. Most work on this lasue has bew in the form of studies calling attention to the problem and recommending solut lons. Such studies are being carzied out in Senezal, Camezoon, Maurteania, Senege1, among others. In several countries, concrete stops beve been taken to reduce allowaces. Bollvia, Laos, Guinea, Senegal, and Cameroon bave reduced non-wage allowaces (bousing in Cameroon), 1o-kind bonefits (rice rations in Gulnes and special perforinace premia in Bolivia.) Bowever, avallable data suggest thet, in geaeral, virtually so progreos has been made on this front. As Table 6 ladicates, aon-wage benefits an percentage of total compensation have lacresed on the average by nesely 8 percent for those countries that experienced a change.

It is claimed that the Camaroon has also igatficanty reduced the number and extent of allowances, but data do not ubow any improvement between 1986 and 1988. Bollvia has offleially taken actiona to reduce berefits, but data on the results of these measures have not yet been collected. One reason for the slow movement on this lssue is the difficulty is getting systematic information and disontangling the enormously lntricate wabs of benefit structurus. For many counzeles - - in partlcular, those in francophone Afrlea -- it may weld be that reform will only result from a smple declaration aullifying the entisety of the present convoluted benefit aystem, and replacing it with a rational, salarybesed reward syetem. Unfortunerely, it is politically diffleult to dispense with non-wage mechandsms without redreselng the ladequacles of the ealary structure which etimulated the emergeace of non-wage distortions in the first place. Bolivia's receat attempts to legislate a rationul salary system have been clrcumvented, for example, by spontaneous non-wage bonus featuree to reward some employese outside of the strict wage igstem.

Equallzing Par Discrepancles 
Inequities in pay among various parts of sovermment have also been the target for rationalizatlon. In Mauritania, salary discrepancies among different central government ministries for comparable work, and the affects of inequities resulting from irregularities in employment status, were both the subject of studles financed by the Bank's Development Management Project.

Closing the gap in par and benefits mong different parts of the public sector was the gosl of some reform programs. In Jamalca, and many other countries, parastatal bodias were able to attract qualified candidates away from the civil service with substantially higher saleries. SAl III instituted conditionality that higher lovel manegament poses in the civil service be remanerated te 85 percent of equivalent grades in statutory bodies through a three-phese pay hike. Although ewo ralses for managers did occur, tha opposition to differentiel rage lncreases from unionized civil servants at lower skill levels prevected the third increase from being enacted. As a result of this delay and the continuing wage orosion through inflation, quallfied professionals and managers conelinue to be in shore supply in cantral government. II

\section{Simplifying the Selary structuge}

In som countries, simpliflcation of the salarg grid has resulted from pay and grading study recommandations. Studies bave been carried out in Barkflanaced programs in the Gambia, Ghana, Guinea, Doulnica, and Jamaica, for example. In Dominica, the romuneration eystom, consistiog of over 100 pay scales, we converted to a stucture of 14 for middle and lower management; almose all jobs are now included in thls new pay scale system. In Guinea, consultants undertook a job evaluation sxercise and reduced 19 grades to 12.

\section{Wage Compression and Decompression}

Bor many counteies, the erosion of average wages was the big problem to be addressed by pay reform. But, particularly in Africa, a principal objective of pey reform is the decompression of the wage structure. This is essential, givan the difficulties in recrultment and retention of higher level staff whose galaries have suak to very low multiples of the lowest ranked workers. (Table 7 shows some compression ratlos for selected countries.) Decorapession of the salary structure was a defintte im in Ghane, for example, where in 1984, before the SAC I program began, the compression ratio was approximately 2.5 to 1 . It rapidly moved to $5.7: 1$ in that year and by 1989 . 1t had decompressed to 7.8 to 1. The Government's stated objective of achleving a 13 to 1 ratio by 1991 may of way uot be reached, but it is clearly moving in the right direction. In the CAR. Eive years of reform produced no perceptible change in the compression

11 Methodologles for determining the approprlate pay levels in the clvll service are only now belng developed. In Jamalca, a comparative pay survey was carrled out throcigh the Adninlstrative Reform Project, the Inst/tutlonal counterpart for pey reform In SA. III. But the survey took so long to De ce-jleted that the ARP was terminateo before the results becane known. S/mllar surveys . ipe carrled out in Ghana, the Gambla. and Thalland to determine the approprlate pay levels for clvll servants. 
rat10. And in Laos, salarles decompressed from 3 to 1 to 6 to 1 under a prograw supported (10 lts later stages) by the Fund and the Bank.

Por other countries, progress is much less clear. During the reform period In the Gambie. for example, salaries appen to have become more compressed in the first years of adjustmant, moving from 8.5 to 1 to 5.7 t.0 1.. (This might here been due, in part, to the ineroduction of the new, shorter twelve grade structure, howerer.) In Gulnea Blssau and Senegal, as well. It would also appear that scilaries compresed further during the reform period, from 5.2 to 1 to 4 to 1 is the former; to 7.8 to 1 to 6.8 to 1 in the latter. It mast be underlined that all these flgures should be taken with a lasge grain of seit; the tend to be "guese-timates", besed on sketchy data.

\section{Salars Supplemeats}

Where reform of the salar structure has not been lminent, a number of countries have resorted to interim programs imed at atcracting qualified professionals into government. Salars supplements are the most coumon mechanisu used to compensate for low civil service pay at upper echelons. Although no syatemetic documentetion exists, eslary supplements appear to be widely utilized. Iramples lnclude Mozambique, Bol171a, Oganda, Gulaee Blseau, Cameroon and N1ger, among others. Is councries where Intermatlonal donor assistance provides in

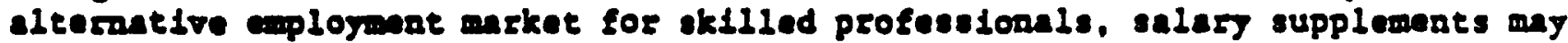
be proolded by. externally flanaced projects in several different ways. Civil

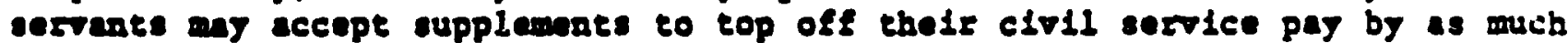
a 400 percent (as in Mozambique or Bollvis), whbout taking leare from the governmant rolls. Indeed, In Moramblque (and elsontere) Bank and other donor projects have hired Individuals working lo ministries to staff special project undes et higher salarles while setll retalaing theis goverment. Jobs. The obvious conflict of lnterest potontial here is enormous. Moreover, the demonstration effect for those govermment employees lacking eccess to toppingup benefits can be devastatiog.

Some c ill servante may take leave or actually separate from the civil service. Whits this is a "cleaner" arrangemant in principle, the cost may well be the loss of the skilled Individual from government service over the short and loag run. In counerias such as Mozambique where human capital is so scarce, this bralo drain could paralyze govermment functlons. Koreover, on a large scale, such supplementation is affordable only with astained external financing. The sphoning off and rewarding of the bast and the brlghtest undercuts government motivation to improve condielons for the majority of individuals. On the other hand, salary aupplements are rlewed by many Bana steff as unavoldable. They are seen as the only way of obtaining good staff to run projects and programs which, presumably. Will enhanre the functioning of the clvil service, and restart the process of economic growth. The argument is that the loss of time and money that would occur with infertor staff is worth both the hlgher remuneration, and the demoralization of the unaffected majority.

In som countrles, salar supplements conslst of those payments provided to higher level civil servants over and above thele clvil serolce grade salagy. Ihese pagments are offered largely because it ls feared that, without copped up 
salardes, the most capable personnel will be lured into lnternet lonally flnanced projects or, better-paylag parastatal. or (where this is an option) into the private sector. There is litele doubt that salary stpplemants have a corrosive and distortiog effoct on clvil service moralo and managemane. Most important, the undermine the possiblitties of mosniogful structurel reform in the longer term. The insidious aspece of thts problem is that in many lnstances the offenders are the donors, including the Bank. This is so despite the Bank's overt policy of dot financlag goverrmart salarles.

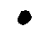

In a for lnstances, Lnsovetions have been proposed to deal with this problem. In Bollota, Intermational donors coutributed $\$ 0.3$. 6 mill1on to form - Coundation to flanace $500 \mathrm{key}$ hlgh level govermmant positions .. all performance eveluated -. outalde of the budget and outelde of the Dy targets

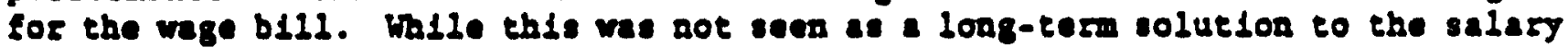
problem, It was viewed as a means to brias some order to the cheotle pay supplement stuntion. In Ghans, the Bank assisted an inovative Sk111s Moblilsation Schem to flance local consultancles for key govermant posit lors esecatial to the econonic recovery program. Bees for these consultancies vere to be at local private sector rates -- well over clvil service levels -- and the posteloas were not to be fllled by eerving goverament emplogees. The 1des was to attract okilled profeselonalo tron the private sector, and perbaps oven repatrlate skilled Ghanaians 110108 overseas. After conslderable dabate over the term of thase contracts, the scheme me ade operat onal. but appears to bave had litele impace. At tim of witelag. forts-one indifidunis have been identifled as ilgible for the scbem and registered on a consultants roster. but oily three govermmat slote have ectully beea f11led through this mechanlsm.

\section{Parastatals ro. Cantral Government}

There are varlous aspects to the salary oupplemagt problem. Attampts to epproach parity between central govermment galarles and parastatals were contemplated, if not always fully carried out, in Jamalcs, Ivory Cosst and Bolivia. Such attempts sometimes result in a "no-vin situntion." First, the equalization of state enterprise saleries with those of central government agencies is often not achlevable; all that can be accomplished is to arfrow the gap between the two in order to stem the flow of quallfied staff from one to tho other and to mitigate somentat the resentmant of civil cervants at recelving rolatively lower salarles. Second, even in cases where parity has been legisleted. the locentives to performance of state caterpilses themselves cannot help but be aegatively affected. To the degree that paraxtatals behare more like central goverment agencles thas private of competitio enterpises -particularly with regard to salary and persornel pollcies -. parastatal performance is likely to suffer.

\section{Inst itut tonal Arrangement Issues}

The Bank's Interlocutor(s) in programs to reduce the size and contain the cost of the clvil service have generaliy been the Ministry of plnance and the Mlalstry of the Civil Service. The tendency of the Bank to sentralize its iscus on these core agencles has occaslonally oversimplified the complicated map of 
Latitut lons involved in varlous phases of cost-coneainment. In the Ghane case, the fallure to percelve and being on board the enedrety of agencles involved in the procese resuleed in destgn mlstakns and delays in impl: noretation. 12 In other Instances, the fallure to underseand that institut lonal arrasgenonts is countries are more decentralizad and less controllable than donors would like (or are accustomad $t 0$ ) hes led project designers to underestinnte the potentisl for noncompliance with reform objectives. Again to Ghane, the exclusion of the Ghana Educstion Service from redeploymant discussions contributed to a misperception of the chnese for post-freeze rocrudtmant of teschers.

Internal Bunt procedures are also factors affecting the outcome of the reforms experiences discussed bove. One element lncreasingly recognized as cruclal to the proparation of pay and ouploymont programs is diagnostic sector. work in enticipation of and in conjuncelon with sAl design. Much of the uneven progrese noted at varlous polnte in this paper in the Ghane reform program might vell have been mitigated by adequate dlagnostle work that mapped out the strengthe and wexkseses of the instltutlons that would need to be lnvolved in the program. An "Institutional assesament" of this type might have resulted in a strategy which established the objectives, and the weje to reacis them, of exch stop of the reform program.

\section{Inact of Cont Contaiment Reforga}

The above discusalon has focused malal, on aspects of implementation of goverrmant pay and amploymant reforms through Bank operations. Although a fair amount can be determined bout how these programs are working from this implementational perspective, ange of the rest contribution of these reform programe can only be achleved by looking more closely at their outcomes and trying to asess the degree to which they have accomplished their stated objectives. (Note gain that the usual warnings obtaln bout the limited extent and low quality of the data.)

Wege B111 Impect

The primary objective of most reforms wat to reduce the aggregate wage b111. To what extent has thls occurred in recent years? Is there any way to link changes (positive or aegative) in the wage bll1 to Bank-aponsored government pay and amployment reforme? (Table s how wage bill trends for selected countries). For the fifteen countries with avallable data in which elther the Bank --through a SAl or a TAL -- or an IAR program sponsored reform, ten (twothirds) had wage bill increeses for the last two jears. Moreover, this group included those countries in which the reform program had progressed furthest, such as Ghane, Jamalca. Guines, and the Gamble. In only four countries did the wage bill decilne is absolute terme. In aine countries, wages and salarles rose

12 As noted by J. Talt Dev/s in "Aovlew and Evaluation of Ghana's Clvil service Reform Progranno:" Consultant's Report, AfTPS, World Bank, October, 1989. 
salardes rose as a percentage of total expendltures. Moreover, the percentage of total expenditures or goode and services or materials and supplies, the tadicator of the avallablitty of necessery inpute for govermment staff, declined for seven out of the group and rose ondy for four. (Por Togo, the percentage of current expenditures spent on goods and services declined for the last year of avallable data). For the other four countrles, data were not avallable.

To repest, these dets are not very robust and lt would not be wise to overgenerallze from them. Indeed. there may be any number of good reasons why the wege blil rose in these countries that are completely urrelated to civil eorvice roform programs. It is not posaible to explais reliably the 1dlongacratic reasons for each wage blll increase. Even for cases where it is posesble to probe data more desply, the ressons for lncreases in the wage bill can be rery ambiguous. 23 Horeover, oven at the aggregate level, the time lag betwea reform and Impact may be longer than can be captured in the available e1gures. It 18 poseible that these results will only be pisible in fueure data องts.

It should also be noted that personael expendsture trends often do not show up in the aggregate rage bill flgures. They can bo hidden in the budget in griad other (often aos-ltemized) categories. Thus, some of these wage bill flgures ma actually understate the total amount of personal enolumedes for a given rear. Taking $a 11$ these cavest lato account, howrer, the date suggest that the 1mpect of these reform programe on egsregate wage bill reduction is negl181ble.

The Increase in overall wages and salarles expenditures may be due to general pay hikes awarded to clvil secvants to alleviate the exosion that had been affecting govermont salaries in many countries -- again, especially in Afrtea. As bas been polnted out earlier in this paper, this general wage erosion affected different classes of civil servants differently, and higher lovel professionals salartes had fallen to dangerously low levels in many cases. Thus, the pessible "good news" in a higher aggregate wage bill might be the decompression of the salary structure from top to bottom.

Data on wage compression are poor. Table 7 shows changes in only six cases. Of these, half the wage structures showed decompression and half showed compression. Looking a bit more closely at ladividual reform programs it seems clear that Ghane bas made progress in decompressing its salary seructure, and Bark ataff confirm loproved morale among upper echelon personnel. In the GAR, It would appear thet not much decoupression hes occurred. And the compression - ituatlons in Guines and the Gambla are lase encouraging st11h. Despite reform programs, wages have actually become more compressed. In the Gambia, this is especially disturblag ince a hotly debeted salary lacrease of approximately 25

13 In Bullvia, for example, where more detalled analyt/c work has recently been completed on publle sector wage and employment trends, the increase w/gnt be explained by a rlse in employwent (Derhaps with decilning average wages) or an increase in average real salerles. The data for that country are so anblguous that it is imposslole to argue elther case w/th confldence. See Barbara Nunberg, Bollvis: A Revlew of Publlc Pay and Emojoyment lssues " 1990. 
percent was awarded in 2988.

Anocher posslble explanation of wage bill increases might be the zatfonalization of the romuneration structure. As noted. non-wage benefits and ellowances hawe traditlonally constituied an important component of the overall compensetion package. These benefits have ofcen been unevent diseributed and heve rarely been linked to performance-besed silieria -. or eve need. In nost countries laformntion about these benefit structures 1 unavallable to pollcy mikers. And, of course, the more fmportant the non-wag benefit contribution to the overall compensation package, the more is is like 1 to distort the general distribution of remuneration, thus making cuilculation of compression ratios among vartous ievels of the civil service at. best onl lodicative of resd remuneration relationships.

Emplorment Reducetons

In the abseace of clear improvements on the flscal side, the overal objective of employment reduct 100 retalne importance. Has this been achieved under these prograns? Table 9 shows the limited data available on employuent troads for selected countries which heve undergone some form of employment reform. For the fifteen countries for which date are avallable, alght were able to reduce goversmant employment durige this pertod. Among these, one (Ghana)

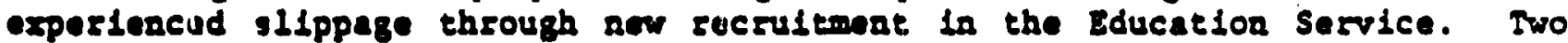
nebnrs -0 Jamnice and Cimeroon -. experlenced slgnificant reductions in recent jears, but then reversed the trend slighty during the last rear. For the other countries, the rate of growth ramined relatively constunt during the reform period.

In general. these reductions were of smil magnitude. The limited impact on she vage bill for those few cases where results have been even modesty encouraging may be a funciton of the very low levels of employment cuts that. countries are beiug asked and are willing to make. Indeed, it may well be that more serious impact can only be achieved through more drastic reductions.

It 1s also important to notg that the saving achieved through government cuts were generally not sufflcient to pay for the subsequent salary increases awerded to correce prevlous civil service wage erosion. Indeed, preliminary ovidence from Ghans and the Gambla suggest that aggregate pay increases rastly outstrip the savings accrued by the retrenchment exercise. Tise discrepancy betwen the relatively small flscal savings of retrenchment and the genezous pay bikes is pertially explained by the extreme wage erosion that had taken place Io many comeries in recent years. It is not likely that significant redress of this erosion could be achleved through anything less than masive employee lay-offs, the likes of which have not been contemplated or carried out in any of the present cases. Finally, most employment reduction has taken place st the lower pay levels of the clvil service. This has tended to mitigate the financial impact of the redundancles.

PATE B: IBS LONG VIER: CIVIL SERVICB MAMGEMIENI 
Short-term efforts to correct glaring and burdensome distortions in goverament pay and amplojmant practices heve clearly dominated the Bank's operatlonal agenda in civil service reform. However. With the advancement or coupletion of emergency surgery, many governments -- with Bank support -- have begun to focus on longer term issues in civil service strengthening. The "long vien" transcends cost-containment to concentzate on detalled, slower-paced reforms atmed at lmproving levels of effectiveness and efficleacy of goverament adntniatrative sjotems. The grand objective of these "ratlonalist" reforms is to ereate or streageben a capacity for personnel pollcy formulation and for dayto-day managenat of the civil service. Onderlytog the longer-term approach is the recogalt 100 thet shorter-term mesures must be supported by lostitutionalized gyotem that cas sustain ongolog reform.

To the exteat that development manegemeat laterventions are Iinked to pollcy-based reforms, they may be distingulshed from the oublic administration assistance activities of other donors working in this field (particularly the Onited States Agency for Internat lonal Dovelopment [USAID] and the Onited Nations Departmat of Technology, Co-operation and Developaneat (UN-DTCU]). These lateer have tended to engage in extensive, diffuse, tratilag and improvement programs, often linked to particular projects, wth litele pollcy focus and fen links to preclse, masurable, lostitutlonal outcoms.

at?

In essence, the Bank's long VIm, nore "ratlonallst" reform programs aim

- Inatrlilag-la civil eervices-personael loformatlon and mangewat syotems, more tightis linked to payrolls, and lecluding clear and appropriate career dovelopment schemes;

- sesfe audits. to determine shat personnel is on hand;

- improved trainiag syateme;

- rovielon, usualls meaniog simplification, of the legal framenork goveratig the clvil service; and

- getting the right people Into the administration, partly by rezonger lacentives to ateract and retain them, partly by changing objectives and procedures in an effort to make the work steustion more chalienging and rewerding.

Civil service mangement reform has been dealt with in a series of techalcal eseistance projects of relatively recent origin. The main activities of these developmont masement operatione are outlined below. The discussion then raises a set of lmporeant implenentat lonal 1seues, and concludes by drawing the first discernable lessons from these operatlons" results.

SLace 1981, approximntely 23 TALs have supported cloll service management reform prograns. 16 Most, though not al1, were in Sub-Saharan Africa. Most of the operations here been apecifically IInked to institutional reforms contained

14 some of these Tus were only partlally devoted to development managenent issues and thus cannot be strictly classifled as development manegement pro/ects. 
10 sale. (The remalntag have doen supposedly freestanding profects, but even - falr number of these have had as indirect ralation to SAL reform programs.) Thero 1s do formil model for reform that can be applied unfformly across courefles, but thare are ideatiflable sets of ectivitles which most of these projects heve in cremor. These meseures are presented below according to the phesed order in which they usual?

\section{Components of Rat lonal1st Reform Leforts}

\section{Date Collection and Anstrats}

In the lesst developed countries with weak reporting and records systems, the flrst need is to tetermine the sacts; 1.0. to determine the number, personal characteristics, okills, yesrs of service, pay, etc., of the civil service. In sowe caess, there bas been a colncidence of this data collection exercise and a civil eervice cansus (Mnurleanda, for lnstance). In others, such exercises may couplement or supplant provious censuses which were methodologicaliy flawed or did not 30 far enough in collecting partinent informnt 100 . Thts was the case for Ghane and the Gambls, Zor example. Is While tho-consuming and expensive, there date gathertag and analjets exarcises provide the date base for the establisbmat of effective records manganat practices. This mans improving reg1stry procedures and bullding sgetems for the ongolng collection, eg8regetion and analyais of personnel data. Iven la the short run, a mapower data base for the cifil oervice is essential to devising and implemonting retranchment serategles. They proolde daformetion that sestses in the determination of prlority araes or ministrles to undergo functional reviews (discussed below), for example, or they help establiab the scope for staff savings in various emplogmant categories.

\section{Introduction of Conputerized Parroll Punctions}

C1011 service management Improvement programe financed by the Bank often have Lncluded support for the rat lonalization and computerization of the payroll mechanisa, usually located in the greasury in the Ministry of Flonce. (Ghana, Senegal. Maritania, Oganda aze a fer examples). In some cases this computerization hes proceeded on 1ts own; in others, the payroll system has been linked to the lmproved personnel mangement data base discussed above. . Explicit IInks to the kidget have also been forged. In several countries, implementation

ISIn Ghana, for example, the orlginal $1986 \mathrm{clvil}$ service census and the wanpower survey carrled out by the Headcount Comaltte in 1987 to Identify ghost workers were successful in indlcating in broed torms the overall numbers and distribution of c/vil servants, but were technically flewed in other ways that llalted thelr usefulness as a managenont tool. For example, the data were collected and stored manually, making cogregate andysls dlfficult and tlmo-consuning; the "Dopulation" was not clearly defined so that it wes not posslble to tell exactly what the percentage coverage or response was; certaln key pleces of sumary dersonnel Informatlon were not collected; and, the surveys were "ono-off" exerclses with no provislon for malntalning or updating information. 
of this Lategrated system has not been carfied out, but the management tals have provided support for studles to produce recommendations and the technical rationele for the implantation of such a network. The lntegration of the personnel dara and the payroll and hudgetafy information is somewhat cumbersome administrativaly and institutionaily as it involves the coordination of various organs: ministries of finance and civil service, statistical institutes, computation canters and techoical line ministries are usually all involved. But comprahensive and sustained control over personnel management functions cansot occur without a linked system. Furthermore, the greater the degree of decentralization of personael management, the more cruclal an integrated network becomes. Most govermments (and several donors) have been easily seduced by the appeal of computerized payroll systems, but there has been greater resistance to the notion of an lategrated payroll-personnel management information system.

\section{Functional Reviows}

Functional geviews have been a common feature of Bank-sponsored civil service management reform efforts. Such reviews afe in essence organizational audits on sample or selected priority list of central zoverament agencies. Their overall ain is to determine the appropriate match between types and numbers of staff, and tasks of functions of government. In adjusting countries, these reviewe bave sometimes been burriedly devised and rapidly implemented. Thus, they have not alway met the most flgorous standards of productivity measurgment. Nonetheless, functlonal reviens do represent a rough, often best available, effort to determine the appropriate number of personnel and the type of skills necessary to carb out the organizational objectives of varlous component parts of goverament.

To some degres, the term. "functional review" is a catchall for a range of related or sinilar activities, including:

- Job Inspections -- A Job inspection program revlews the structure and staffing of sgencies in goverment to determine: what work needs to be done to fulfill the organization's objectives; whether the organizational structure is appropriate for lts activities; whether the staffing numbers, grades, and levels of responsibility are appropriate to the needs of the work; and, whether some degree of consistency is maintained across agencles.

- Organization and method studles constitute another instrument used in functional revtows. These aro evaluations of the efficlency of a particular service provided in a imilar way by several or many agercies, and where significant numbers of stafe are employed. The im is to identify main areas of weakness in performance, to find and remove botelenecks, and, in sum, to simplify procedures. This process can yield signiflcant staff savings as well as promote greater efficlency.

- A third technlque used in funcelonal zeviews is budgetary analysis. This Is an examination of financial data in an effort to pinpoint areas where nanpower are being inefficiently employed. This, it is assumed, autometcaliy identifies potentlal targets for budgetary savings. One appronch is to undertake analysis by exception: for example, to pinpoint agencies where the proportion of personal emoluments to total expenditure is particularly high, or where trends in 
persoanel emoluments have deviated significantly from observed trends is other program expeaditure.

- Functionel zeviews often use zat1o analys1s, a means of identifying potontlal problem areas requiring more detalled policy reviews. Ratio analysis 1s tallored to the precise functions and objectives of the organization or sector concerned. Typical examples include medical officer/bed ratios, teacher/nonteachiog staff rat10s, agricultural extens1on officer/population rat10s, and cost of tax revenues collected/eax collector. These ratlos are then reviewed against governmat targets to asalst in highlighting rogional disperities and, in pertlculer, flaging areas of apperent staff shortages of surpluses relative to the average. Ratio analysis is indicative rather than conclusive; it indicates reeds for more speciflc polley reviows, and uledmately to more detalled plans for recruitment, tralning and staff development. In the immediate, it helps identify functlons which are obsolete, overlapplog or otherwise redundant.

The findings of funcelonal reviews lead to the next phase in the sequnce of adnindstrative rationalization; the metchlng of existing personnel to ideal neede. In principle, this should result in the identification and retention of those Individuals with appropriate and aceded sk111s. It should also lead to the reassigoment (and perhape retraining) of staff ouperfluous to the requiremeats of the ageacy under review, but who possess capacitles and potential requised elsentiere in the sysecm. Finally, te should 1deatify the Individuals who are not needed, and should be dismiseco or persunded to leeve voluntarily.

Functlonal zeviews have been utilized in several countries (Ghans, Guinea, Benda, Gambla) to propide a technical basts for declsions concerning employment cuts. Although the heavily rationalist procese described above suggests only an ldeal type, functional reviews of the sort described have enhanced the credibility of redundancy programs, in Ghane and the Gambia, for example. In both countifies, as part of the adjustment process, functlonal reviews were conducted ovér a period of a few months. They vere mainly designed and administered by international consultanes. In Ghana, the consuleants, in confunction with British Overseas Development Assistance (ODA)-sponsored overseas tralning. succeeded in transferzing personsel review technlgues to local staff in the Management Servicos Difision of the Office of the llead of the Civil Service (OHCS), The result was thet a corps of competent job inspectors was bullt from scratch. This successful transfer of technology turned out to be an important and positive feature of the program. It not only boosted professicnal pridn in the OHCS, but also extended a sense of Ghanaian ownership to the redeployment program.

On the other hand, Job Inspectors were not the highest priority among the manporve requirements of the Ghanatan clvil service. Presumably, the demand for chese sk111. will diminlab considerably .. though not disappear -. once the intt1al. cost-cutting phases of the redeploymant program have been complered. In the Gambia, by contrast, virtually no on-site training of local staff was accomplished by the Implementing consultants in the execution of functional seviews. The consultants attributed this admitted deficiency to a number of factors, including intense pressure to produce the reviews very quickly. 
It 1s worth noting that in both the Ghanaden and Gamblan cases, a substantial number of emplopwent cuts (and certalniy those effected in the first months of the reform programs) were made la idvance of the findings of the functional reviows. However, these reviews did, reportedty, help in the Justiflcation and implementation of the second round of cuts. The reason is as follows: the second-round targeted reductlone fell on aress of less obvlous "fat." and the data and recomendatlons of the functlonal reviews provided declelon-makers with "technical" and "Obfective" information with which to contest the varlous groups opposed to the staff cuts. In Senegal, a process akin to the functional reviewe -. called organizational audits -- wes cerried out by the Office of Organizat Ion and Mothods (BOM), managemeat trataing and troubleshooting undt located is the prestiglous offles of the Presidant. The audits of BOK have prograssed mach wore slowly than those performad by consuleants, perhape in part because of difficulties in winning the cooperation and support of key mbaletries in the eadeavor. While there to an advantage to the national control of the senegalese exercise, one mist note the cost of the snatl's pace at which pollej ectlons oteming from these govinre have materialized.

\section{Training}

In-cervice tralaing of clvil eervants elther on-the-job, or in ahort courses abrosd have been a fonture of a number of civil service mangement projects. In several ceses (Malawl, Muritanla) the maln Eocus of profects bas been on streagthoning civil service trainias lastitutes. In Mauritania, a

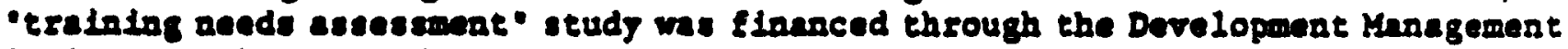
Project, and tringlag arrangement was ecteblished between the Institute of Public Adntaletration in France and the Mational School of Administration (ENA) 1n Maritande to carry out in-service training of higher level civil service

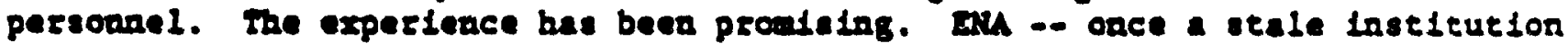
focused excluaively on pre-service training for aw civil service recruits -has tumed its attention to improving the skills of government personel already 1n service. Training is thus serving to relnforce goverrmant' commitment to improve quality and reduce quantity in the civil service.

In Malarl, the sole focus of an Institutional Development Project is ihe tzaining of higher and middle level mangers in the civil service. Increasing

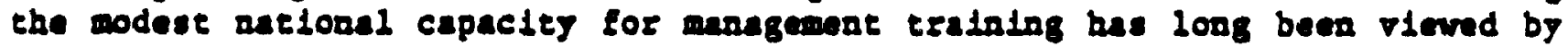
Government as an exeremely high prlority. Thls view has coen to be shared by the Bank, which has attributed recent implemontation bottlenecks in adjustment programs to the cevere shortage of tralned personael in the upper levels of the clvil service. Thua, the project atme at the etreagthening of the Malawisn Iast ltute of Mangement.

Involved Bank staff olew thls profect se aeceseary component to civil service management improvemont. St111, thes are quick to point out that training and sk111: improvement are necesary but not sufflclent conditions for reform. The crucial fact remains that there are fow lnceatives, financial or otherwise, for acwly trained and presumably improved managers to retura to the civil service. Thus, the next and necessary step w111 be to puraue improved personnel policles, Lacentive syerems, pay and employment shemas, and performance 
malueton. Most of the work on the profect to date has been done under a Cenad1an twinalog exezc1se which has worked well as aodel for bullding training sapab111E1es.

\section{Spectel Incentive Schemes for Hlgher Level Clvil Servants}

Weik lecentives syoteme mean wak civ1l services. As discuseed earlier,

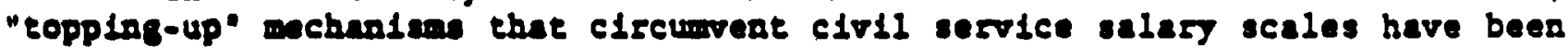
cana is a posible anerer. They are used to ateract and retain highly skilled professionals loto government service, in partleular so thes may perform key ecoacuic recovery program easks. Topplag-up machandam were expllcitly funded In two IALs? the Bolivia Economic Mangemant Strangthening Operat 10n (BMSO) funded a non-govermmatal agency .. a "foundation" .. to channel pooled extrabudgetary resources for kej posts; and the Ghane structural Adjustment Inetleutlogal Support (SAIS) project created a Sk1118 Mobilization Scheme to h150 locel consultante for govermmat positlons at saleries well over civil service levels. Ihese schemes were aimed at creating oomething akin to the established and enduring 0.3 . Sentor Executive service. While they have succeeded ta getting some skt1led people into goverament service, they have so far been seen is short-term, incentive-boostlas achandem, not as enduring instltut 100s. Such lnstrumants have been locluded in development management profects in an attenpt to impose a modtcun of order on the haphazard array of acchenisan crested by governmoses (and often suppurted by donora) to circumrent clvil service rumberation cosveratate.

\section{Poller studles}

studles almed at providing a technical data base for personnel policy formilation bure been an important component of may civil service reform operatlons. Development management projects have financed studies to examine current practices and recomond future ectlons on salary pollcy, personnel mangement informntion eystem creation and maloteannce. general employment policy. civil service tralniag, and career development for civil servants. A aumber of studies have focussed on important but poorly understood topics, such as the system of fringe beneflts and bonuses in senegal. Most of these studies were lneanded to produce aceion programs specifylng the needed and feasible stops of further reform.

It bas bees argued that studies have sometimes substituted for or delayed ection, es in Bolivis and Senegal for example. The ides is that the Bank and governmates ue seudies to avold beloging a conflict, or potential conflict, to a damglag head. Thls cjalc1sm is not entirely fustified, however; studies have often produced sertous thought about loportant and contentlous personnel issues, lacluding wat is the appropriate and affordable role for state agencles, and whet 1s the proper atze and cost of the clv11 service. Studies bave supplied recomandations that form the concrete basis for Bank-country dialogue on these toples.

2. Inplomentation Issues and Lessons in Development Management 
Although many of the activities discussed in the preceding section have just begun to be implemented, several issues meriting ateention have already emerged. The discussion that follow highlights tiav key polnts; those raised most frequently by Bank staff working on these projects.

One perhape unavoldable but nonetheless worrisone feature of these developmant mangemat operat lons is the short-term perspective on which they are besed; 1.e., the quite limited extent to which they bave begun to address the longer-term management 'ssues. As noted, the bulk of supported activities assists SAl cost-contalomant measures. The emphasis on the short-term is understandable but costly. It often comes at the expense of attention to longterm strategy and the aced to build enduring, sustalnable management systems. In Ghane, for example, with the exception of preparing fob inspectors to carry out tasks in support of the retrenchment exercise, I1tele training to build up basic administrative sk111s of the civil service hes jet taken place. In Guinea, the prime goal of IAL I was to reduce numbers in the civil service. So far, there hes been little support for the resolution of longer-term, structural wage 1ssues. A census of the cloll service was performed, but there has not yet been - Collow-up to build an laformation managoment system to install modern, impartial personel reviow and control practices. In the Gambia, the follow-up otafe lnspection program which was to be carsied out by trained Gamblans under the supervision of ODA loag-term technical advisors in the post-retrenchment portod has ground to a halt, possibly due in part to this fallure to internalize these actiplties in the earlier phases of the reform process, and to the lack of counftemate to long-term administrative reform by both government and the Bank.

As noted, Is several lastances couputerized data management systems have been instelled for personnel records and these systems hare been linked to the pejroll and the budget. This is an accomplishment. But the sbsence of a erategic framework for ongoing civil service management is troublesome. In the Central African Republic, for example, concerns have been expressed about inadequate attention to factors essential to civil service performance improvements: career development, training, incentive structures, performance evaluetion systems, etc. The fear is that unless such changes are implemented, even a smaller civil service will remain unproductive. The fundamental questions are the long-term ones What kind and size of civil service does the country aeed? How should it plan to get there? What should be the ultimnte purpose of the reviews of the vartous legal texts regerdiog the wage system, the ledemalty system, the rights and responsibilities of cloil servants over the long beut?

The ebsence of a strategy has not alwags been due to the overridins nature of short term SAi demands or the assumption that cost contelnment ls eve rowhere and always the first priority. In some lnstances it has been due to a deficit of Flston or coherence in the reform program teself. In Jamaica, for example, the Administrative Reform Project consisted of a series of largely uncoordinsted activities -- Lacluding revision of classification systems and pay surveys -the strategic value of which was not clearly deflaed. 
There have been cases in which aversion to strategic considerations was the product of consclous choice. In Bollvis, crestisg a pool of comparatively okilied and well paid civil servants, to fill key government posts, was accomplished -. without onormous difficulties .. through the Economic Management Support Operation (EMSO). But government interest in lazger policy questions (or even studies) on such questions as overald pay and emplojment levels, or career development policies, was consplcuously absent. According to observers, govermment reticence could be traced to the political implications of personnel policy reform: the rationalization of civil service incentives and employment policies would eliminate political patronage opportunttles which are alternatively distributed to the "Ins" and "outs" during electoral transitions. There is thus no clear constituency for restructuring the system.

In some cases, atrategic policy concerns have been crowded out by components the usefulness of which is more imediately apparent to governments. In vauritania. for example, computerization of the personnel manegement system. which eajoys considerable government commltment, has been proceeding on schedule. But a number of delays have taken place in the preparatlon of a serles of policy studies. It may be that changes in administrative technology aro perceived as less threctentog politically than overt examination of existing policies (even though the applicat10n of the technology may sender transparant abuses and fraud by exposing "ghost" workers and double salaries, etc.)

Efforts in these operations have concentrated on reforming systems in the core minletrles of flance and civil service. The costs and benefits of esteblightor clese linkages betwen central minietzies and decentralized organs have not been well addressed. In the Jamalce Administrative Reform Project, for example. decentrallzed personael units were to be set up in line ministries to coordinate with the central Ministry of the Public Service. Bowever, training of sectoral minfatry staff never occurzed, as the ceatral ministry was losthe to relloquish control of personnel admindstration.

The queation of "appropriate technology" and the capacity of borrowers to internalize new management systems and procedures has been an issue in several civil service management operations. Ghana and Mauritania provide two contrasting experiences in this regard. In Mauritania, computerization of the personal managemant system occurred through the application of a technical package that was developed through elaborate fine-tuning by Tunlsian consultants, contracted through a twinning arrangement between their government and the Ministry of the Civil Service. Intensive lnteraction over a perfod of many months renulted in a syetem neaty tallored to the Maritanian context. Murftanians were carefulis trained, and by the end of a rear, were ready to take over the oystem. Bank staff report that the twinning approach worked so well In Mauritanda because of the cultural effinity betwen the Tunisians and the Muritanians: and because the Tunisians had just lnstalled a similar system in theif own county. From the outset. this system was designed to be comprohensive, connecting the pajtoll and the personnel records of the Minisery of the civil service. The design of a comprehensive systen grew out of a detalled diagnostic study undertaken as part of Bank sector work on public sector management in Kauritania. Adequate preparation, detalled diagnosis, approprlate technology, sensitively delivered: these are the building blocks of success. 
In Ghana, by coatrast, the IInk betwea the computerlised payroll systam - completed early in the adfustmont program becsuse of 1 ts importance to demand mangement -. and a proposed computerized personnel mangement system came as an afterthoughe. Where the Tunlsians had carefully crafted a package for the particular aeeds of the Mauritaniens, the expatrinte consultants working in Ghana proposed an off-the-shelf-technology, estimated to take only six months to insta11. The establishment of the Iinkage 1s, at time of weiting, underway; and lt any well work. St111, it seeme likely that tbere will be a tradeoff between speed of installation and the degree of laternelization among Chanaians.

The smple and obvious lesson to be drawa from these contrasting experfeaces 1s that differeat clrcunstances dictate different approaches. Mauritanis we ready from the outset for a comprohensive approsch, in pare because of earbler diagnostlc work and in part because of the good w111 toward the Tunisian conaultants. Although succeseive changes in the Mindster of the Civil service crented discontinuit 1es, the degree of conseneus-bullding necesery amose varlous parts of governmont to win support for the project was relatively modest. Ghans presented a much more fractlous and fragmented context, in which each stap of the roform program had to be sold to a widely diverse constituency. It is unilkely, given the InItial resistance to reform, thet the Ghanaians would have "bought" a coupreheastre personnel syatem is part of a grand civil service reform strategy so early do the reform program. Indead, a good deal of the work of the coneuleantes in Ghan -- which overall has been performed quite successfully - - hes been gradually to gain the confidesce of the 15 counterperts and theroby bulld support for the reform program.

The zelatlonghip betwen development management efforts in tAle and SAls 18 an losue ralsed by Bank staff. Many complained that SAls pushed these developmant managemant operations too fast. Most estimated that the time offlctelly allocated for activit bes we about half of what was actually required for implementistoa. The other horn of the dileman is that TAls not linked to SAl conditionality wer viewed is "toothless." and implamentation of these freestanding projects was mede that much more difficult. Thus, in civil service reform the Bank seems faced with a difficult trade-off betreen realistic, longercerm eimetables and leverage.

In a number of lastances, the sequencling of reforms through tals was haphazard. Sowetimes, a component could not proceed because an unrelated aspect of the TAl of the companion sal would be delayed, thus holding up loan effectiveness or disbursemant. This sometimes serlously threw the phas lag of the civil service reform ltems off-belance. In sone instances, sequencing of activities had to be altered because the time required to bulld consenaus among key ectors had been serlously underestimated. In other cases, tbe Bank's understanding of the network of principal lastlutloanl players was landequate. In at leset one lnstance support for a component was mistakenly aegotiated with the rrong egency.

The relat lonshtp betwen the Bank and other donors has flgured importantiy In derelopment management operations, Other donors such ss the UN/DTCD and USAID have been active on these 1ssues in a number of countries in which the Bank is supporting civil service reform. (Guloea, Ghana, Bollvia and Uganda are examples). The lack of coordination or a clear division of labor among these 
efforts has resulted in overlapplag or conflicelog egendes, where there should be complementarfty. Lack of agrenmat about terme-of-reference for coneultants, operating schedules and stjles hes presented problems -- with varging degrees of serdousness -- is Jamalca, Gambia and Ghana, for example. Delays in project implementat ion heve easued.

The fandliar lament that staff weks for superviston were inadequate to implemantat ton requirements wes particulerly poignant for these operations. This wa true for Bank staff time and for expert consultancles. Bor some aspects of developmant managemnat, such as the computerization of payroll and personnel records schoms, speclalized sk111s bave to be sought outs1de the Bank; but in several cases, resources were not avallable and therafore generallet Bank staff wre forced to supervise -. ofter landequately, they felt -. alghly techalcal componentes.

\section{Observat1ons}

What the sbove discussion of experience suggests 1s that this group of development managenent operat lons constitute a first generat lon of projects whose objectives are. for the mot part. tled to the overall agende of SAls. As such, they heve only begun to seratch the surface of what is reguired to construct (and ocotelne zeconstruct) well-managed and well-performing civil services. Indeed, for the wet pert, Bask latertent lone is this ares have left untouched a wide range of longer-term, structural lssues wose resolution is essential to susealnable inprovements in government sdmialstrative capec157. These laclude

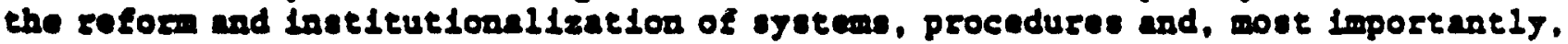
incentive seructures. Thls study show that as the shorter-term reformit are plajed out, the need to effect these underlying sjotemic problems through second and thifd generations of profects is becoming more evident, as is theif complextey. The uncertain and somotimes appareatis lntractable dature of these lesues has already felled one successor adminlserative reform project in Jamaica, where the Bank is now pursulng a more narrow approach to lnstitutional development through a Elnanclal management project to follow upon the first Adminfstrative Reform Profect.

A key conclusion 1s that arolding civil service management problems will not make them $80 \mathrm{may}$. Som staff argue that the Laberently complex and uncertein nature of cloll service reform places the field outalde the Bank's comparative advantage. They argue, or bope, that on this 1ssue the Bank should confine teself to assieting in the defindeton of econonically rational polictes: 1.A., the appropriate and affordable size of the rage b111. But it is wishful thinking to belleve thet one can separate the formulation of pollcy from its implemantation. For prime example, the Bank cannot simply Identify X thousand surplus personnel, and then assume thet the totallty of the job of removing them will be carrled out by the government or a bllateral donor. The challeage for the Bank is to design projects whlch have meanurable short-run cost-contalnment outputs, but to do $10^{\circ}$ in the context of a strategy to solve the more fundamental manegement problems in the long run. 


\section{Part $C_{8}$ Cosclustone}

Despite the oft-mentioned data constralnts affecting the subject and the Eladings of this paper, some lessons to gulde present and future civil service reform are emerglog. These can be sumerizad as follows:

- The impact of Bank programs to contain the cost and size of civil services through emergency pay and amployment reforms has so fac been negligible. Efforts in most countziles to reduce the wage bill and to decrease the number of cledil service omployees have jlelded minimal realutes. Moreover, attempts to correct distortions in the structure of pay and cmployment through the decoupression of wages and the rattonalizetion of the romuneration system have had but limited success. Th1s disappointing record suggests that reforms to date have bean lasufficlently ambitlous in scope to bring about the degree of change that is aeeded. Meaningful change is golag to require more forceful reforms.

- The question of whether more aggressive reforms are feasible is perty - techaical. but mindy a poldtical issue. As mentloned lo earlier sections of this paper, the political economy of pay and amployment reforms needs further conceptual and analjtical work. Nonotheless, it is possible to bypotbesize from the fow ezniples of countrles where programs have been carrled out that the pollelcal costs of implemonting pay and employmant reformo have been lower than most govercmants (and perhaps over the donora) had anticlpated. Organized opposition to reforms hes not resulted in regime destabilization, and social upheaval as a result of dismissals hes not occurred. In part, this may have been - function of the surpelsing capacity of prlvate sector labor markets -. particularly in egricultural and informel sectors, and perticularly, but not exclusively in Africa -. to absorb surplus governmant workers. It may also have been a function of the unexpectedly good handling of political factorg, including the akill with which regimes generated supporting coalitions and managed contesting groups, for example.

What this suggests is that quite possibly regimes can (for political ressons) and must (for economtc resons) make deeper cuts. How far any given goverrment can push these reforms 1s, of course, unknown. But the relatively mild consequences of the minimal reforms undertaken so far can, it is hoped, tofluence goveraments' perceptions of political flsk and encourage them to take bolder actions in the future.

- Most of the middle-range employment reduction mechanisms such as voluntery departure schemes and early retirement programs may be useful and politically astute, when applied in combination with more stringent retrenchment meaures. But they have not yet proven to be effectlve in reducing employment Io any sigalficant manner. Thus, they do not provide abstitute for biting the bullet through explicit dismissals.

- Technical analysis and support activitles such as funcelonal reviews and competency testing, for example, have been useful in providing a rational 
baste for cost-contalomant meseures. Their wafor contribut10a, however, ing be the symbollc assurance they provide that the reform procese hes been undertaken wteb fatr and aquitable latantions.

- Rotraloing, redeploywant, crad1t and publ1c works programa for rodundant

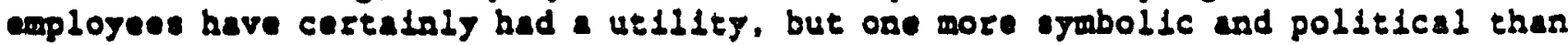
econouste. From a floanctel and techntcal perspective such programs have had Iimited impact and have proved admlalsteatively difficult.

- Som Bank supported reform programs have promoted interim solutions to pay and anplosment problems through speciallzed incertive schemes for topping up executive level salarles for key goverament posts, or, more brosdly, by widely supplementiag civil service saleries through donor flnanced uctivitles. Most observers fambliar with the use of these mechanisms recognize their limitations and costs. The problem is that aeteher herd-pressed governments nor operat lonal otaft have alterontive meass as their disposal. St111, what mast be recognized 1. that these selary supplement mathods do not provide enduring angwers to the fundamantel probleme of cloll service incentives; ladeed, they ultimately undermise the likelthood of devising a durable solut 10n. The Bank should not encourage or unpport euch mechandsms is the absence of an action strategy for logi-term structural reform is goverament pay and employment policies.

- Most sark activitles la cifll service raform have concentrated, understasdably, on the short-term cost-contalomant acesures. Considerably more cuphasis vill heve to be glvan to longer-term mangemant 1ssues $1 f$ sustained improvenat in govermanat admintstzative capacity ts to take place. The flrst geberat $10 \mathrm{n}$ of developmant management profects now underway have taken an important step in this direction. More atention needs to be pald to devising a coherant, over-erching strategr for civil serrice reform, and detalling the set of tactica by which the strategic goals will be achleved.

- Technical Assiseance Loans dealing with clvil service management issues require more staff supervision time and pore resources for spectalized expertise then has previously been allocated. Most estimates suggest that these factors need to be more or less doubled to ensure successful implementation.

- Technical Assistance Loans in Development Management require more time to prepare and 1mplement than do tofrastructure projects. While th1s is wellrecognized, they are too often short-changed in this regard by thelr dependence on both the scheduling and aubstantive requirements of structural adjustment lending. On the other hand, such IAl profit from the association with both the policy focus and the locreased leverage that SAle provide. Without SALs, many civil service reforms in TALs have no "teeth".

- Many of the Lnstlutional obstacles to carging out vitally needed clvil service reforms can secm overwhelming and insuperable, especially when confronting the "long-haul" problems. Indeed, the mlred record so far on many of these 1ssues could d1scourage further efforts. A frequentis observed response to thls state of affates hes been to decry the Bank's lack of "comparative advantage" in this fleld. But a retreat from civil service management reform is tantamount to a denisl of the crucial importance of government administrative capacity to implenent economic and social programs. A more realistic approach 
36

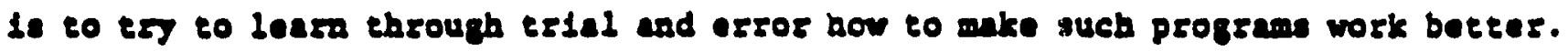

-

- 
rates 1

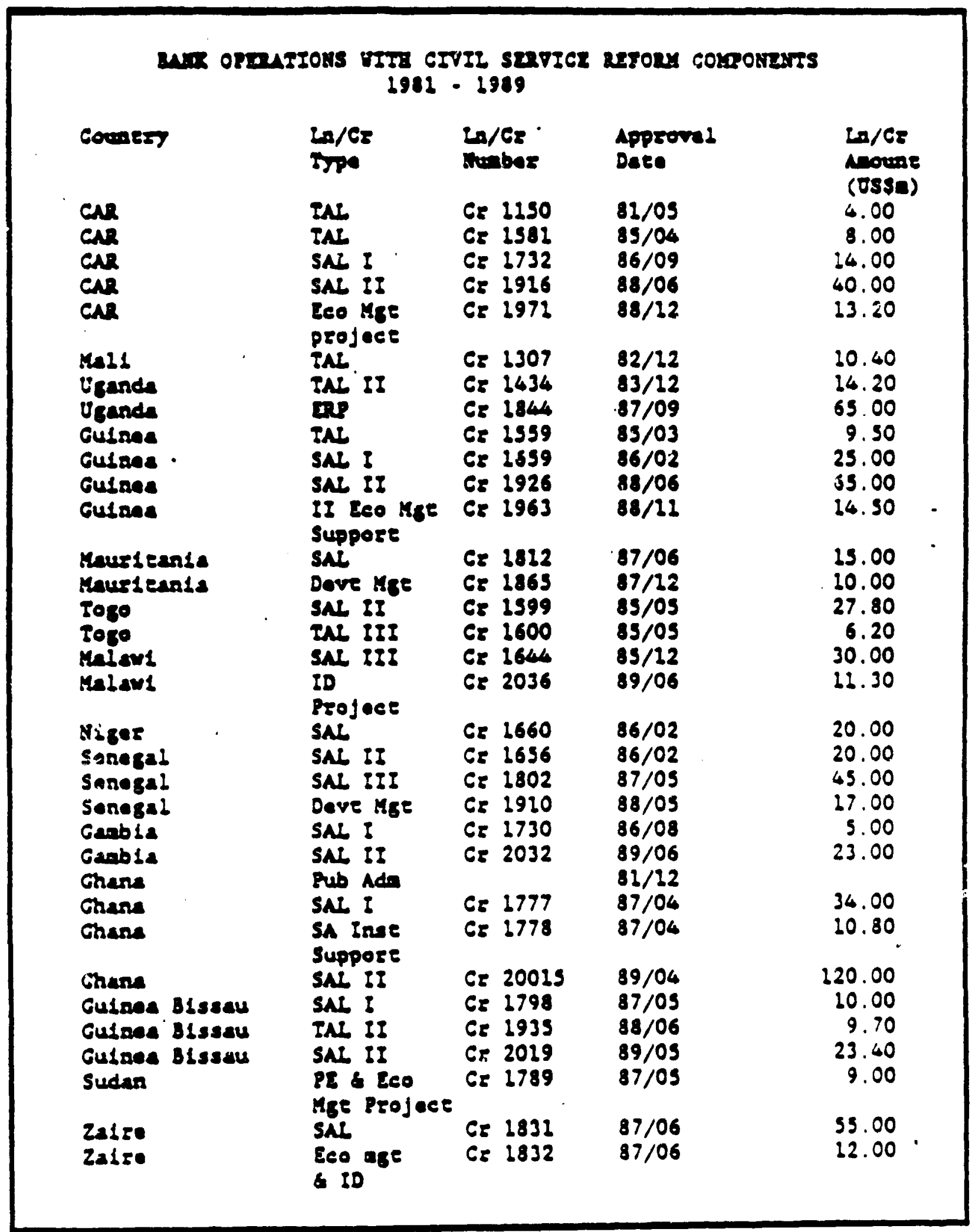


TAIS 2

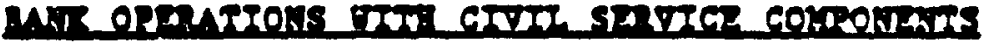

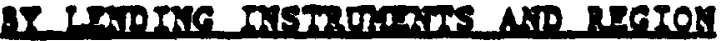

\begin{tabular}{|c|c|c|c|}
\hline Begroa & sates & jues & rotes. \\
\hline Afetes & 23 & 18 & 62 \\
\hline LAC & 7 & 4 & 11 \\
\hline Exena & 4 & & 4 \\
\hline Aota & 4 & 1 & 5 \\
\hline Toeal & 38 & 23 & 61 \\
\hline
\end{tabular}




\section{IAQLE 3}

componguts of civil sovice acron

\begin{tabular}{|c|c|c|c|c|c|c|}
\hline $\begin{array}{l}\text { Stcudtes } \\
\text { eleanest lese }\end{array}$ & 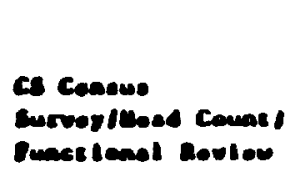 & 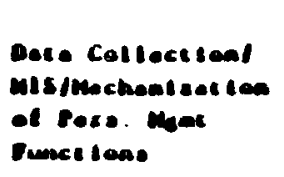 & 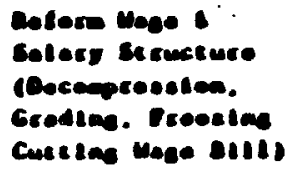 & 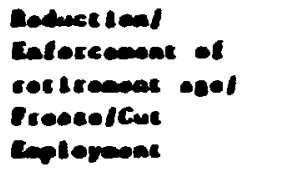 & 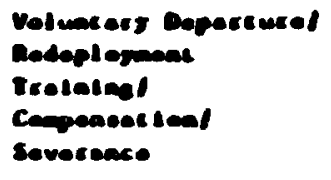 & 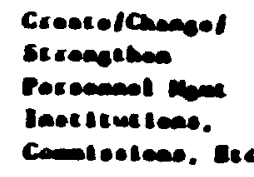 \\
\hline 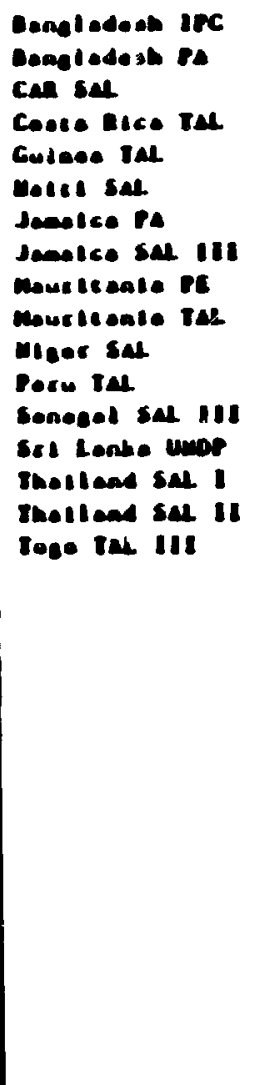 & 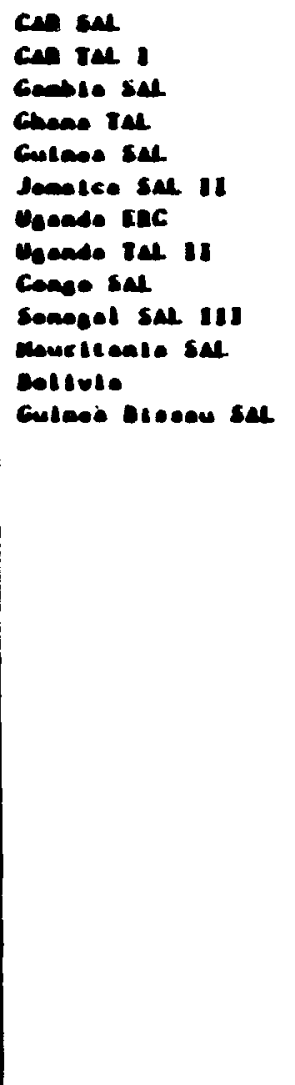 & 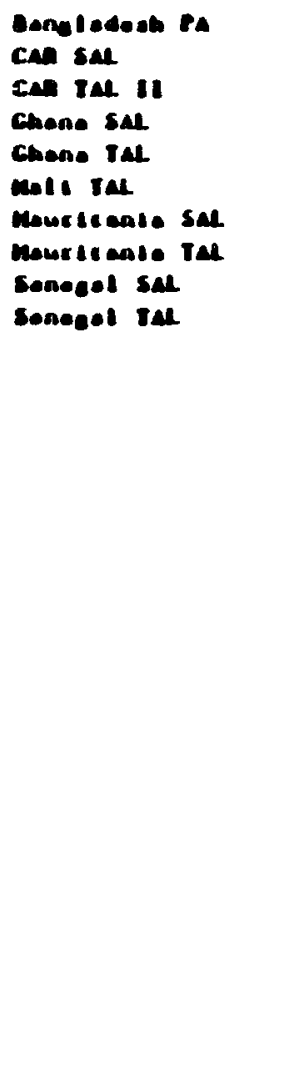 & 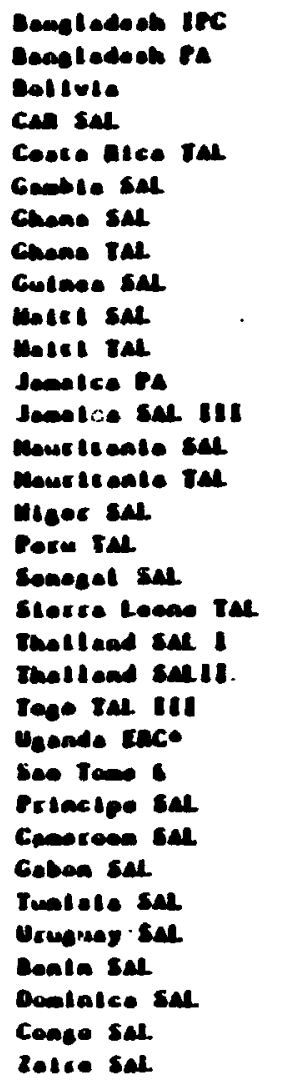 & 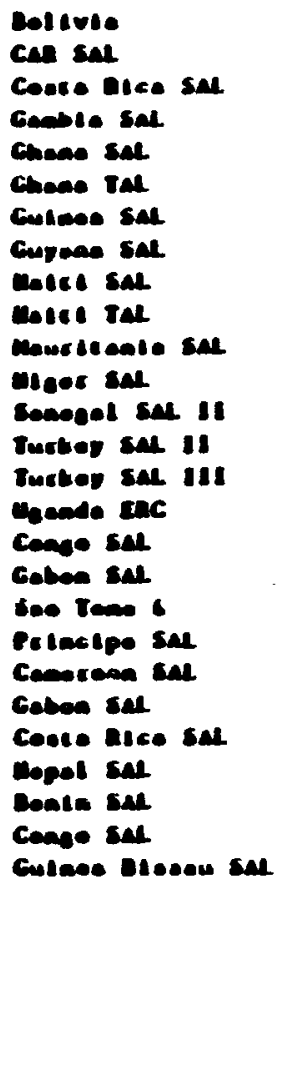 & 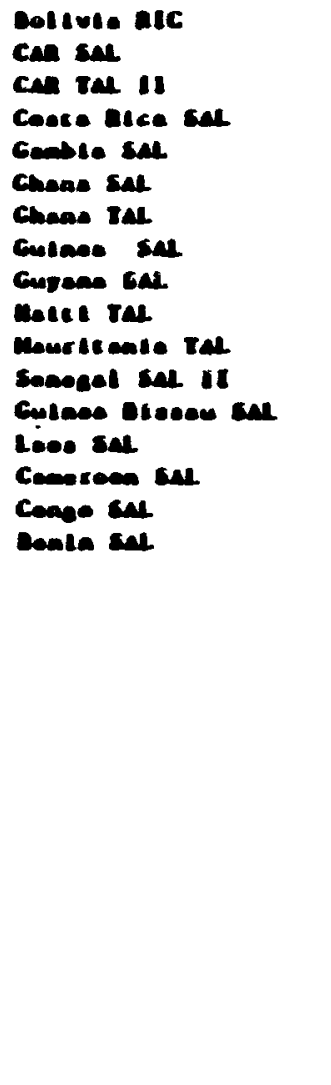 & 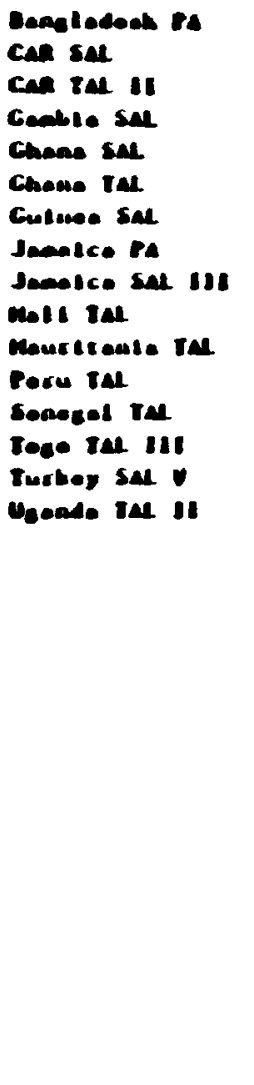 \\
\hline
\end{tabular}




\section{Iab!e_-}

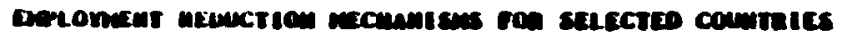

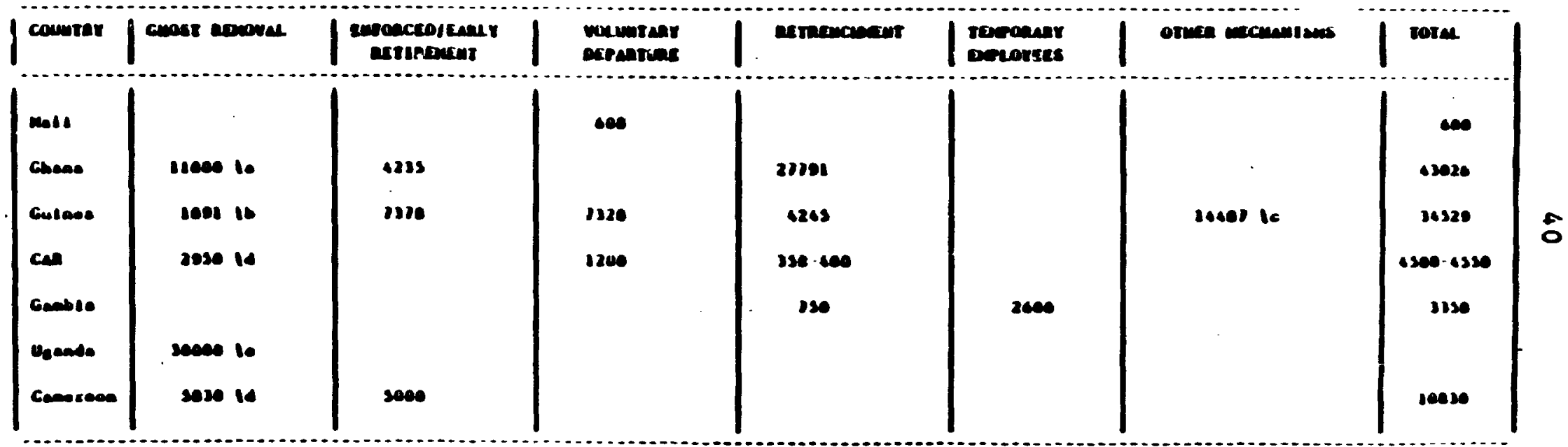

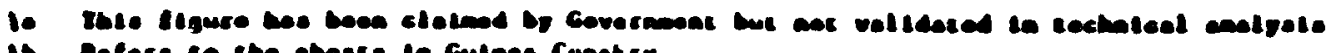

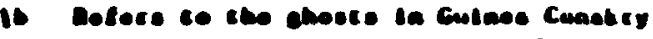

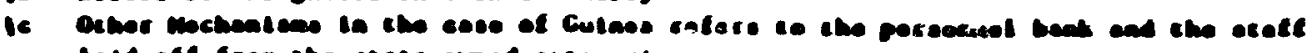

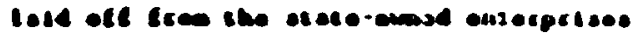

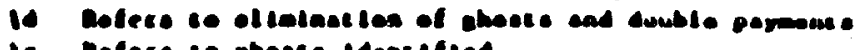

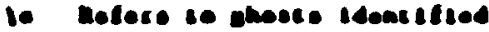

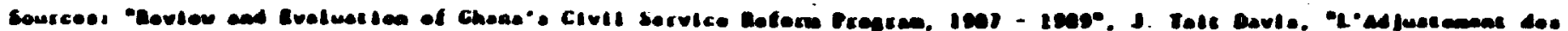

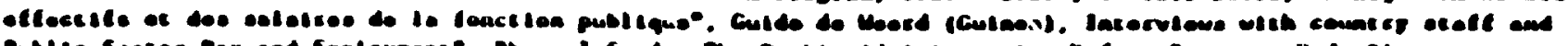

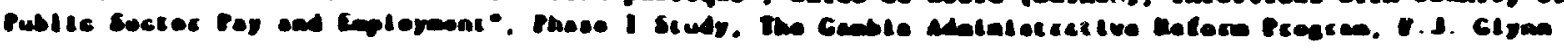


TABLE 5

\begin{tabular}{|c|c|}
\hline Gouners & Formis \\
\hline $\begin{array}{l}\text { Ghane } \\
\text { End of Serotea } \\
\text { awasd }\end{array}$ & $\begin{array}{l}4 \text { wonehs baste salary } \\
2 \text { wonehs besie salary on } \\
\text { eeralnation elwes } \\
\text { coupleced years of service }\end{array}$ \\
\hline Gulnos Blssau & $\begin{array}{l}\text { I year's salary paid } \\
\text { on a anchly basis }\end{array}$ \\
\hline $\begin{array}{l}\text { Coneral African } \\
\text { Republic }\end{array}$ & 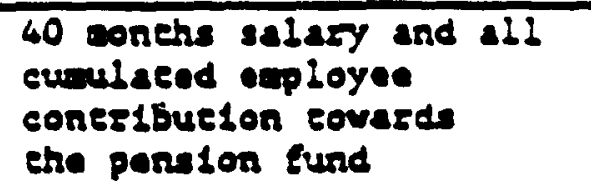 \\
\hline Les & b. yeas's sabary \\
\hline GuInora & $\begin{array}{lc}\text { Grade relaead amouncs } \\
\text { Inoune } & \text { Index } \\
400000 & 207.312 \\
450000 & 332.960 \\
500000 & 580.773 \\
550000 & 787.5050 \\
600000 & 1129 \cdot 1347 \\
650000 & 1406.1525 \\
700000 & 1604 \cdot 1980 \\
750000 & 2139.2614 \\
800000 & \text { Above } 2164\end{array}$ \\
\hline
\end{tabular}

Sources: Country seaff 6 Recull des Texens Stacuealies de la Fonceion Publique Gulnoenne 
TABLE 6

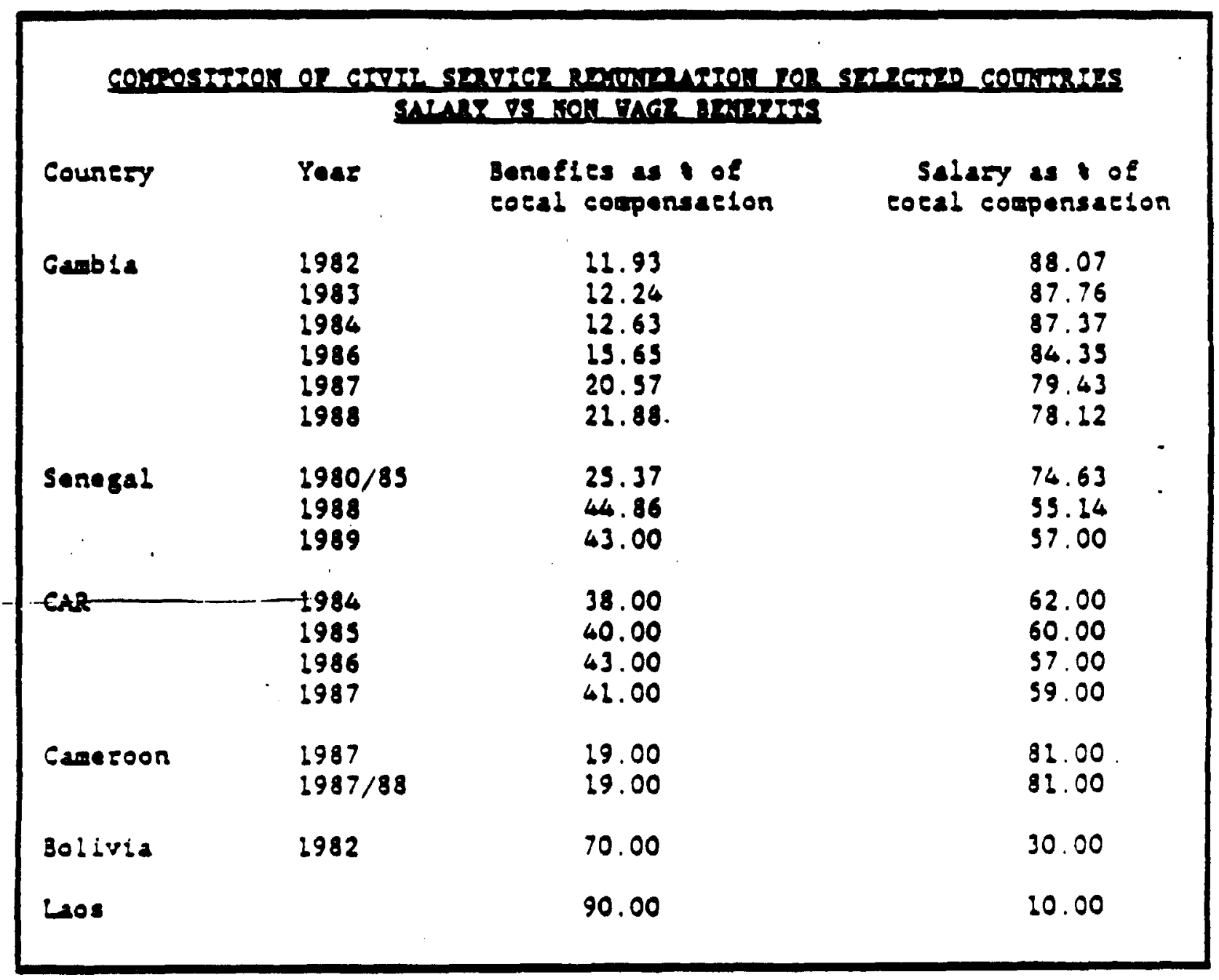

Soureas: Counery seaff, Staff eselaces, Coopers Lybrand rapore "Elflcactea de la Fonceton Publique Progran do Reducion" (Senegal). Daes provided by the Ganbian authorieles. 


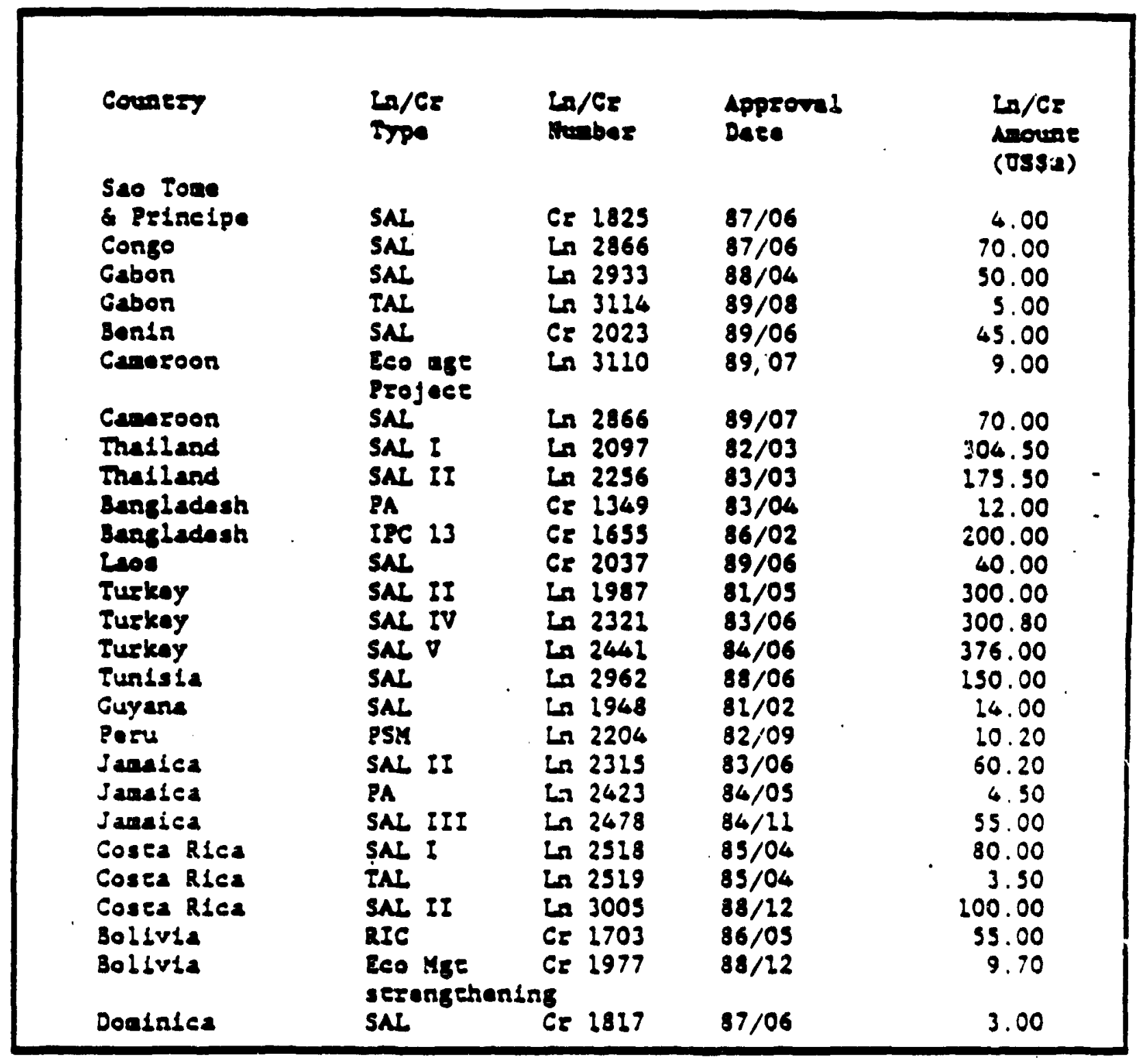




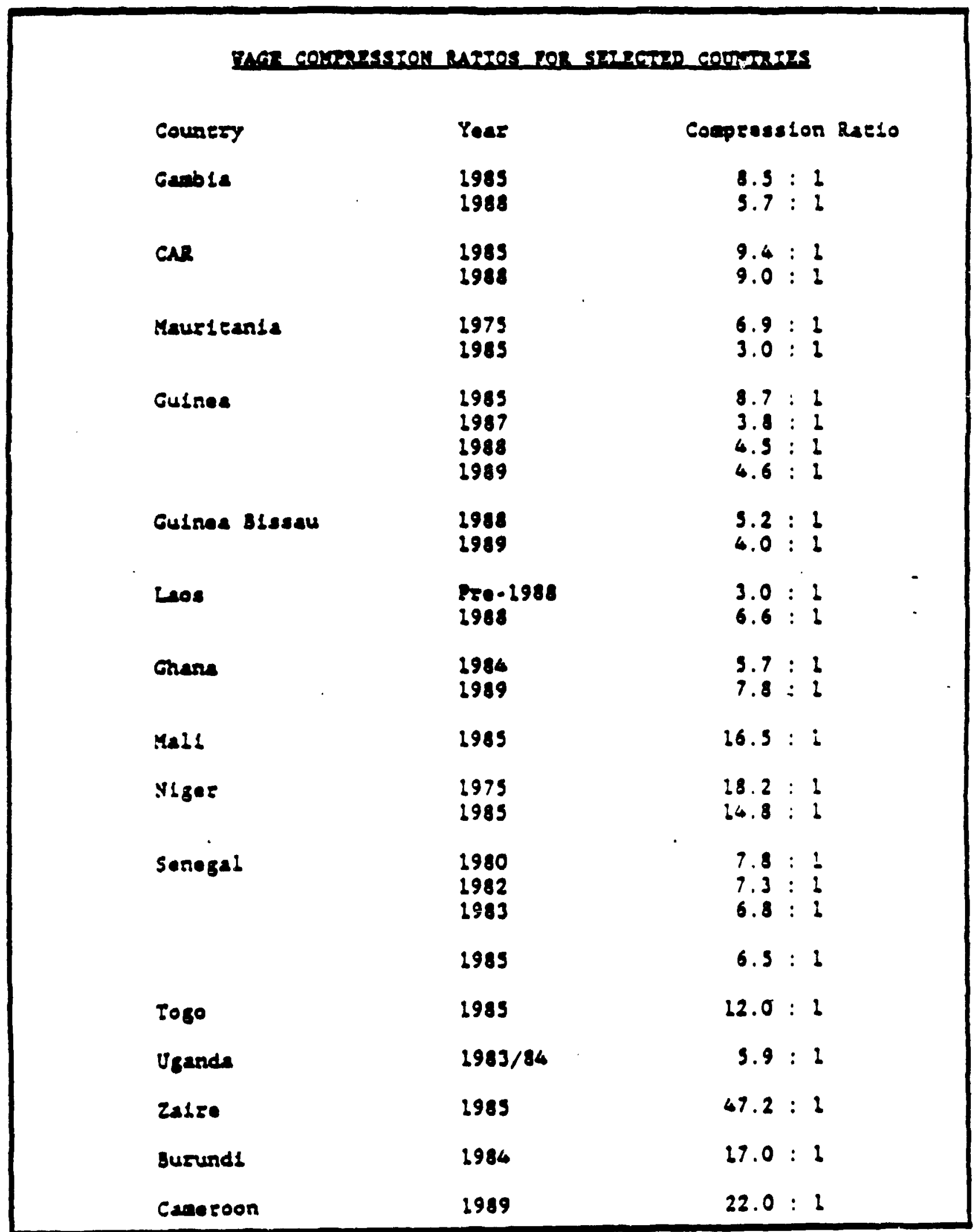

Sources: Counery seaff. Depareanenco de Informeflea (Culnea slssau) and daea providad by ene Gablan auerorleles. Prollatinary daea Ezou D.Robinson: Clvil service pay in Afrlea (Genova. TLo. Eorehcoaing) 


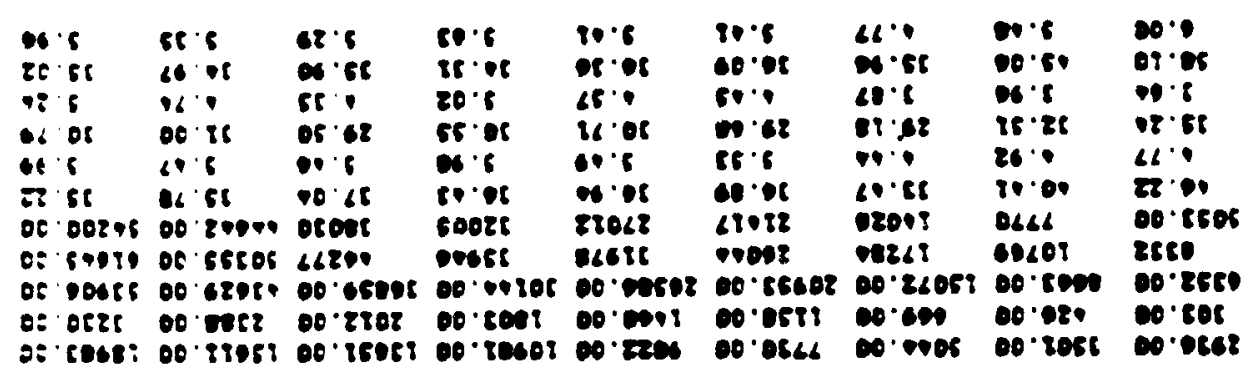

091600 i6 08.66

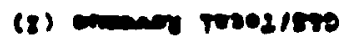

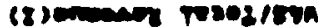

(8) emsternes resicte

(8) Ematron poogisin

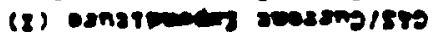

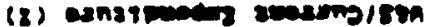
coming roos enatrum roses consiver smasers cooranes ormos onveres wo coun

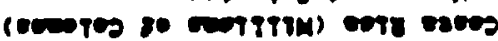

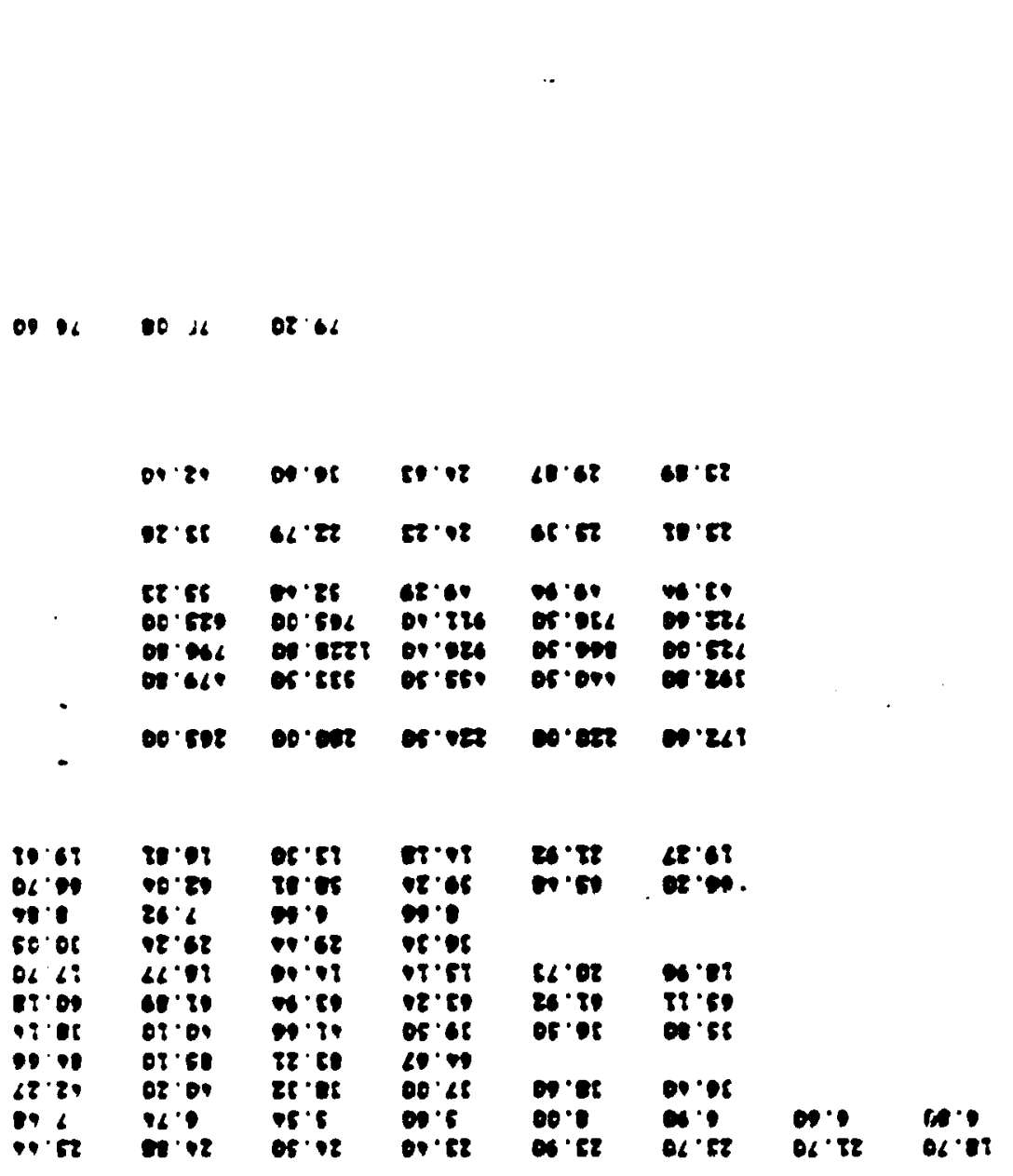

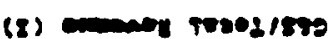
(8) vimen Toezicha (8) ermarwer roes/ses (8) emstran resise

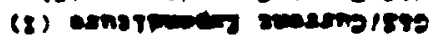

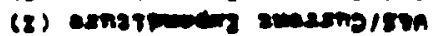
inmeres ematwer roes

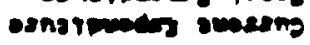

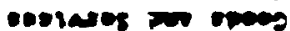
eerrepes wh ceven

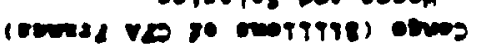

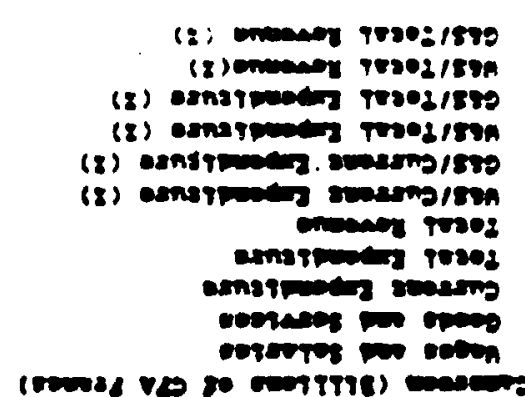

(8) mmace poesine

(8) cumen Treesirin

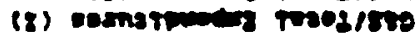

(8) cemarwate reostren

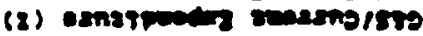

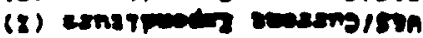
cumare Tres enerpung poes

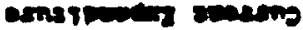

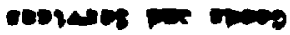

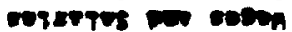
(tomes vo ro matties iv

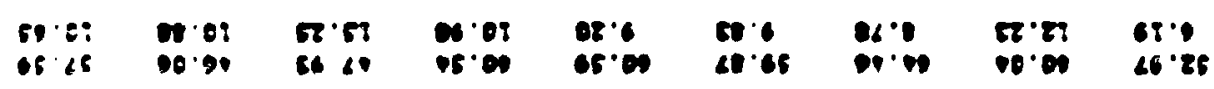

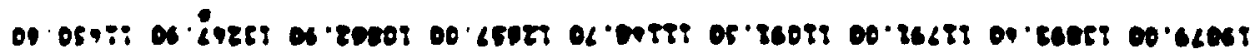

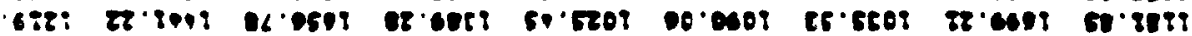

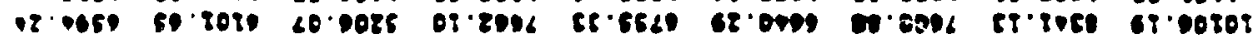

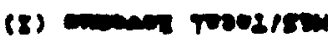
(8) Tum Tresisen

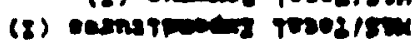

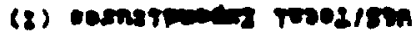

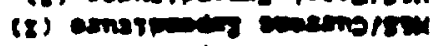

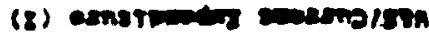

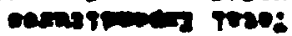

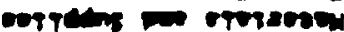

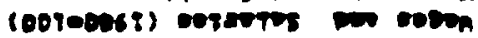

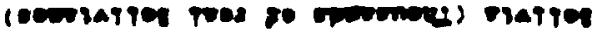

106

(1)

-es?

061

res?

ses?

Los?

Res?

cos? ximase 


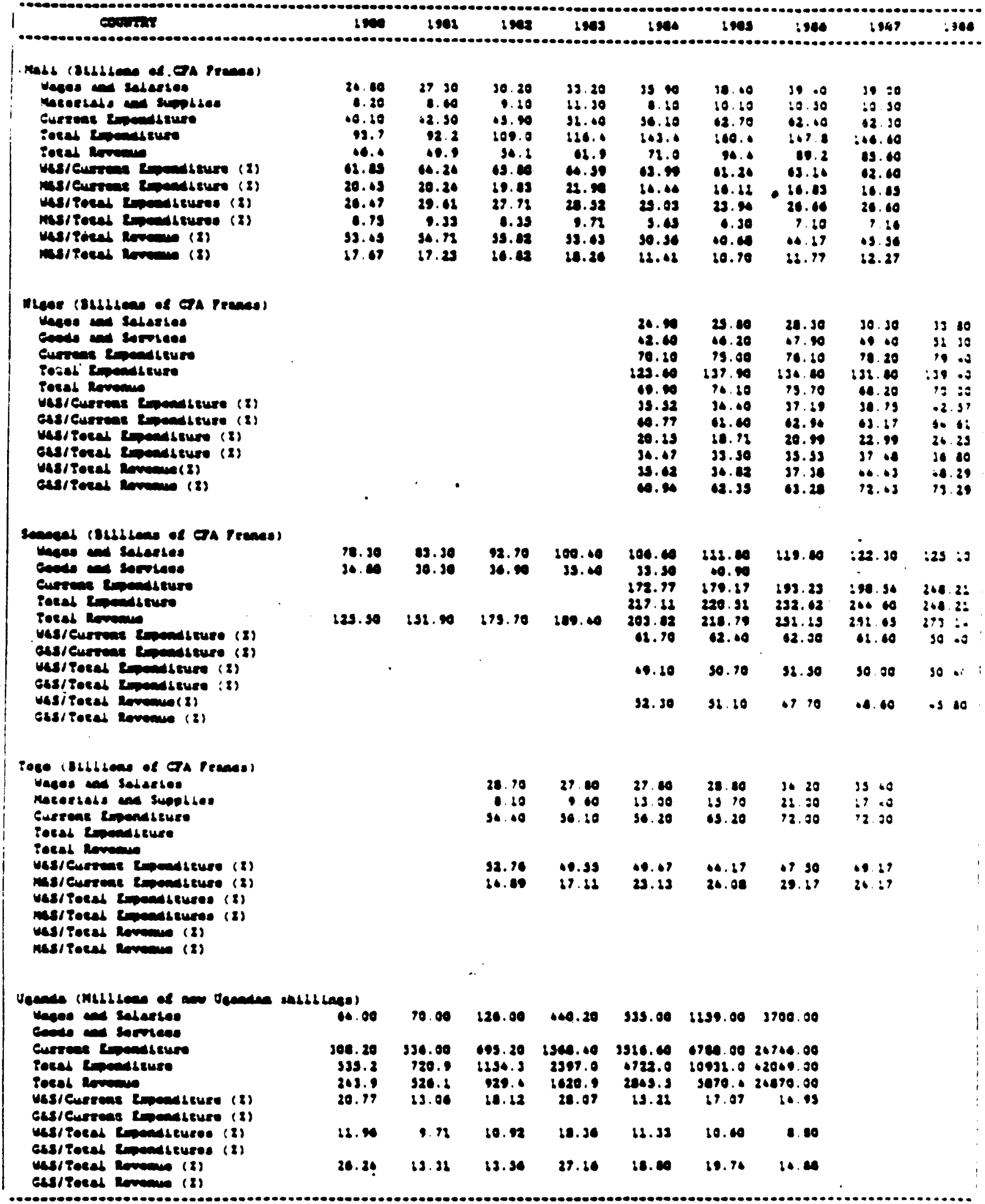

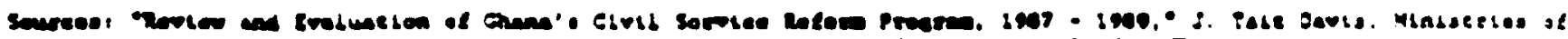

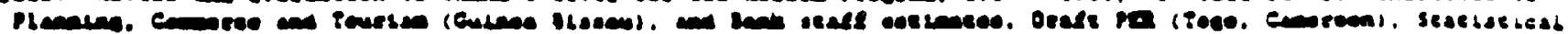

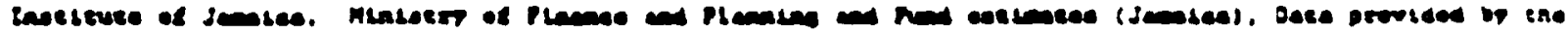

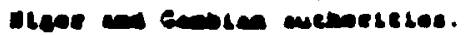







TABLE 9

exre sanes Dronar

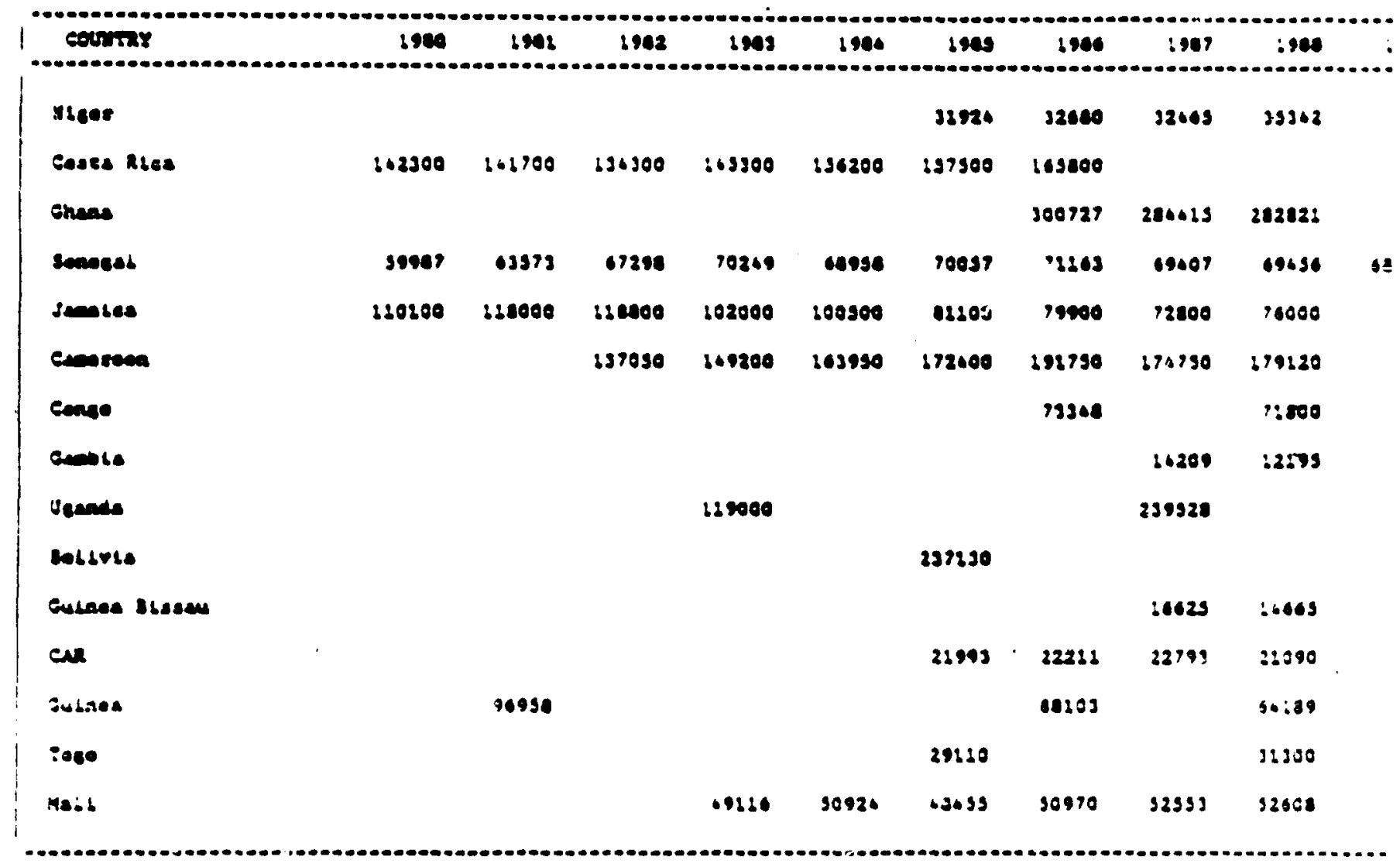

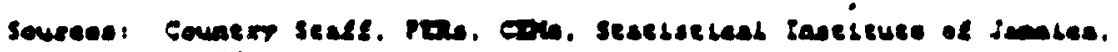

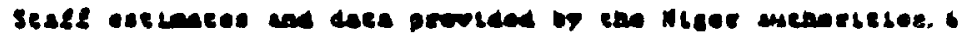

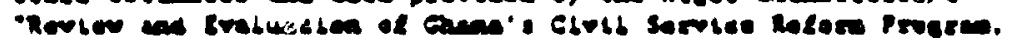

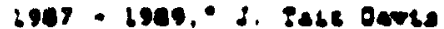


Annex 3: - "Box"

\section{CIVIL SERVICE COSI CONTAINMENT}

Containing the ceneral govecmment's wage blit ho- been a prisagy objcetive of civil serotee goform in the Canteal Aft an Rapublic (CAR) and Ghana. In boch countefies geform has been supporzed by seruceurab adjusement lending and ecehnical assiseance frov the Horld Bank Group.

In the CAR, where the wage blil absorbs over 60 of doaestle revenues. Initial seaps focussed on disposing of "ghose" workers and then blaifing the eocal numbers employed. Hovever, ehis approach did nee work well because agenetes replaced bow-pald workers by rectuitirg sfaff at higher lovels. :e was then declded to lapose a liale on the wage bill in 1987, with fureher reducelons in 1988 and 1989 . This was to be done aainly by surpending regular annual 1nerenents. The wage bill has, in face, declined only slighely in each of the fisse wo years (1987.1988). Aesention is now also beginning to focus once nore on redueing the slze of the eivil serviee.

- Reform in Ghana began vith the eliainaeion of what the government has clatued to to be sone 11.000 "ghosts" 850 the govermane paysoll". "Menagenene appraisals" vere etren undertaken by ceans of officials

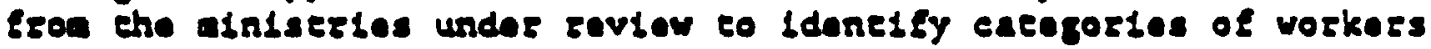
chat were overseaffed, wichoue reference to individuals. The appraisals concenezaced ca the 30.40 lowest pay grades (out of 130) on ehe assumpeion that this was where the anin probled lay, and recommendsetons wero made as to the number of positions to be abolished. The recomendacions were reviewed by a commicsee of senior eivil servanes which decided how many, and who,

should be recrenched. Ministers then reviewed the efreumseances of each one of the individuals recommended for cermination, eaking inco account not only their performance, bue theis years of service and number of dependencs, as well as whechar ocher meabers of the facily were govermene employees and vere also beling enrminated. Only afear ehis serueiny were people actually disnissed. The net resule has been a reducetion of cenceal government empioymene in the gange of 30.000 plus over four years. Hownver. ehis has not yoe led co any budgecary savings because there has been a general (and badly needed) increase in civil service pay adjuseed for inflaelon. eogecher wish a slighe widening of differentials between the highese and lowese paid, and because savings fron seaff reduefions have been wore than offset in the firse three years by the coses of compensation.

the rafio of the central governmene wage bill to GDP (agound st) has in face increased slighely. 


\begin{abstract}
Ah elvil servanes in the CAR weze given the option of Leaving

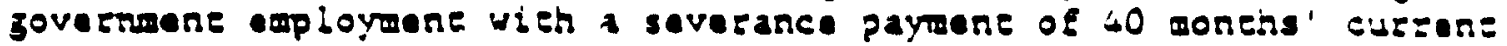
sabafy, plus any personal coneribucions they had aade to the pension plan (co dace these payeents have averaged over U5\$20,000 pez head). As of Auguse 1989, about 1.500 people had applind for voluneary reefrenane under this schise, and 300 had actually left the service. Yeanwhile, plans for the dismissat of redundane employees are proceeding very slowly. Those not designated as ossential by theis agency eneer a coneral personnel pool, and ay be hized by ocher agenctes if etrey have approprtace qualifleactons. Those not selected in either round are supposed to be disabased fron the service on cerms auch less tavorable chan for voluncary reelremene, bue with some assiscance in obealning aleernative employment and access so credit to soe up in business or farming. However, no disabsals have yee eaken place.

In Chana each disalssed civil servane recelves Eour monehs' base salary, plus wo wonehs' pay for each year of serrice, and the average severance package for chose cerminated ehrough oid.1989 has. been estimazed at the equivalone of 2.94 yaers of pay ( 1.96 years for teachers). The suppore progran for those who are re-deployed includes information, counseliling and placenene services, training opportunities at exiseing vocacional and cechnical eraining cencers and ausiseance in agrisuleural producetion through provision of land. inpues, extension services and eranaielonal food aid.
\end{abstract}




\begin{tabular}{|c|c|c|c|c|}
\hline & Inte & Aluthos & Dat? & $\begin{array}{l}\text { Contace } \\
\text { boreasoer }\end{array}$ \\
\hline WPS416 & $\begin{array}{l}\text { World Bank EHorts at Povery } \\
\text { Mosaurememt in the Third World: The } \\
\text { Living Standerds Measurement Study }\end{array}$ & Faul Giemwe & & \\
\hline WPSA17 & $\begin{array}{l}\text { Modding the Mesrocconomic } \\
\text { Requirements of Poliey Retorm }\end{array}$ & $\begin{array}{l}\text { Walien Eastenty } \\
\text { E C. Hwa } \\
\text { Piyabha Kongsanut } \\
\text { Jan Zizek }\end{array}$ & May 1990 & $\begin{array}{l}\text { A. } 1427 \\
34303\end{array}$ \\
\hline WPS418 & $\begin{array}{l}\text { Does Devaluation Hun Private } \\
\text { imvestment? The Indoneaian Case }\end{array}$ & $\begin{array}{l}\text { Ajay Chnibers } \\
\text { Nenne Shafik }\end{array}$ & May 1990 & $\begin{array}{l}\text { M. Colin= } \\
33490\end{array}$ \\
\hline WPS419 & $\begin{array}{l}\text { The Design and Sequencing of } \\
\text { Trade and Imectmom Polioy Reform: } \\
\text { An institutiond Analyas }\end{array}$ & Erian Luy & May 1990 & $\begin{array}{l}\text { 3. Levy } \\
37488\end{array}$ \\
\hline WPS420 & $\begin{array}{l}\text { Making Benk Irrigation Imvostmems } \\
\text { More Surtaincble }\end{array}$ & Gerald T. OMara & May 1990 & $\begin{array}{l}\text { C. Spooner } \\
\text { 30484 }\end{array}$ \\
\hline WPSAR1 & 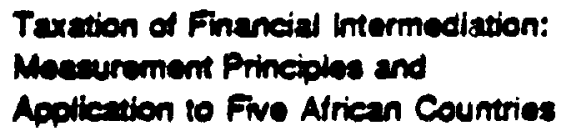 & $\begin{array}{l}\text { Chriatopho Chamley } \\
\text { Pariat Honohan }\end{array}$ & Mey 1990 & $\begin{array}{l}\text { W. Pitayato. } \\
\text { nakam } \\
37666\end{array}$ \\
\hline MPS422 & $\begin{array}{l}\text { Civil Service Relorm and the World } \\
\text { Enit }\end{array}$ & $\begin{array}{l}\text { Babare Nunborg } \\
\text { John Nellis }\end{array}$ & May 1990 & $\begin{array}{l}\text { R. Matooim } \\
37495\end{array}$ \\
\hline WPSA23 & $\begin{array}{l}\text { Relative Price Changes and the } \\
\text { Growh of the Public Sector }\end{array}$ & M. Shahbaz Khan & May 1990 & $\begin{array}{l}\text { WDA OHIica } \\
31393\end{array}$ \\
\hline WPS424 & $\begin{array}{l}\text { Moxico's Extemal Detor } \\
\text { Restructuring in 1989-1990: An } \\
\text { Economic Anahyia }\end{array}$ & Sweder van Wijnborgen & & \\
\hline WPSA2S & $\begin{array}{l}\text { The Eamarting of Covemmem } \\
\text { Revenues in Colombie }\end{array}$ & $\begin{array}{l}\text { Wiliam A Mocleary } \\
\text { Evamaria Uribe Tobon }\end{array}$ & & \\
\hline WPS420 & $\begin{array}{l}\text { Growh-Oriented Adjustmem } \\
\text { Programa: A Statiatical Analysis }\end{array}$ & $\begin{array}{l}\text { Alceardo Faini } \\
\text { Jaime de Malo } \\
\text { Abdel Senhadi-Semiali } \\
\text { Julia Stanton }\end{array}$ & & \\
\hline WPS427 & $\begin{array}{l}\text { Exchenge Poform, Parailel Markets } \\
\text { and Intlation in Alrica: The Case } \\
\text { of Ghand }\end{array}$ & $\begin{array}{l}\text { Ajay Chtrbect } \\
\text { Nema Shatik }\end{array}$ & & - \\
\hline WPS488 & $\begin{array}{l}\text { Perestroyka and its Implications } \\
\text { for European Sociatist Countnes }\end{array}$ & Bela Bakand & May 1990 & $\begin{array}{l}\text { N. Campoell } \\
33769\end{array}$ \\
\hline
\end{tabular}




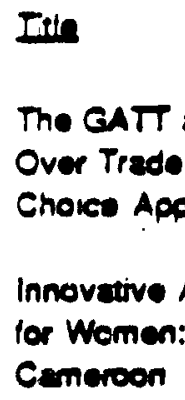

WPS404 Chila's Labor Markers in an Era of Adjuatomert

WPS40s Imvatments in Solld Wate Mencoemem: Opportunities for Emironmental lmor. vemem

WPS400 Tomahip, Villege, and Privere Induster in China's Economic Rolom:

WPS407 Publis Emororice Relom: A Chalkenge for the World Bank

WPS40 Methodologied bsues in Evalusting Deresticueing Douls

Lis A. Rivero:

Cart Bartone Janis Bematoin Fiederidx Wright

Witian Byrd Alan Cos

Anmed Golel

Stin Clesesons

bhes Diwan

WPS409 Finandel Polley and Corporate Imvestmon in Impertect Capital Markets: The Case of Korea

WPS410 The Cost of Gaphd and Inveatment in Developing Coumnes

WPS41" Institutional Dimensions of Povery Reduction

WPS412 Exchange Rate Policy in Developing Coumries

WPS413 Supporting Sate Mothemeod: A Reviou of Financial Trende Fut Repon

WPS414 Supporting Sate Motherheod: A Review of Financal Trenda Summary

WPS415 How Good (or Bad) are Country Projectiona?
Mansoor Dailami

Alan Auertach

Lawrence F. Salmen

W. Max Corden

L. M. Howard

L M. Howerd

Noman Hick Miched Vaugeors
Maren 1990

N. Aris

38010

Aonl 1990

R. L14 34303

April 1990

S. Cumine .23735

April 1990

K. Chen 38968

April 1990

G. Oriaca-Tonen 37648

May 1990

S. King-Watson 33730

Apnl 1990

M. Ragganidi 37857

Apni 1990

A. Bhala 37699

May 1990

E Madrona 37498

May 1990

M. Corden .39175

Mey 1990

S. Ainswonh 31091

May 1990

5. Ainsworn 31091

Aont 1990

M. Borg 31058 